University of Miami Law School University of Miami School of Law Institutional Repository

2013

\title{
Empirical Fallacies of Evidence Law: A Critical Look at the Admission of Prior Sex Crimes
}

Tamara Rice Lave

University of Miami School of Law, tlave@law.miami.edu

Aviva Orenstein

Follow this and additional works at: https://repository.law.miami.edu/fac_articles

Part of the Criminal Law Commons, Criminal Procedure Commons, and the Evidence Commons

\section{Recommended Citation}

Tamara Rice Lave and Aviva Orenstein, Empirical Fallacies of Evidence Law: A Critical Look at the Admission of Prior Sex Crimes, 81 U. Cin. L. Rev. 795 (2013).

This Article is brought to you for free and open access by the Faculty and Deans at University of Miami School of Law Institutional Repository. It has been accepted for inclusion in Articles by an authorized administrator of University of Miami School of Law Institutional Repository. For more information, please contact library@law.miami.edu. 


\title{
EMPIRICAL FALLACIES OF EVIDENCE LAW: A CRITICAL LOOK AT THE ADMISSION OF PRIOR SEX CRIMES
}

\author{
Tamara Rice Lave* \& Aviva Orenstein**
}

In a significant break with traditional evidence rules and policies, Federal Rules of Evidence 413-414 allow jurors to use the accused's prior sexual misconduct as evidence of character and propensity to commit the sex crime charged. As reflected in their legislative history, these propensity rules rest on the assumption that sexual predators represent a small number of highly deviant and recidivistic offenders. This view of who commits sex crimes justified the passage of the sexcrime propensity rules and continues to influence their continuing adoption among the states and the way courts assess such evidence under Rule 403. In depending on this image of sex crime perpetrators, legislators and judges have ignored the contrary psychological and criminological evidence. Most critiques of the sex-propensity rules concentrate on the unfairness part of the Rule 403 equation, but we approach them in a novel way, focusing instead on the absence of empirical support for their so-called probative value. This Article examines the empirical support for the probative value of such evidence, revealing that current policy rests on bogus psychology and false empirical assertions. Rules 413-414 typify the regrettable seat-of-thepants psychologizing on which evidence rule drafters rely too often; the approach eschews a nuanced approach to questions of recidivism and the different types of sex offenders. We argue that rulemakers should look to the disciplines engaged in the empirical study of perpetrator behavior before asserting notions of deviance and recidivism to justify radical changes to evidence law. Finally, we offer specific guidance to judges about how to conceptualize the probative value of evidence of prior sexual misconduct and how to incorporate this knowledge in applying their discretion in admitting sex-crime propensity evidence.

* Associate Professor, University of Miami School of Law.

** Professor of Law and Val Nolan Fellow, Indiana University Maurer School of Law. The authors would like to thank Professors Hannah Buxbaum, Seth Lahn, Leandra Lederman, Edward Imwinkelried, and Miguel Mendez for their helpful comments on earlier drafts, and to thank Alexandra Block, Jason Howard, Sylvia Orenstein, David Szonyi, and Caroline Wong for their invaluable help in research, editing, and technical assistance. 


\section{INTRODUCTION}

Presume not that I am the thing I was, For God doth know, so shall the world perceive, That I have turn'd away my former self

\section{William Shakespeare, King Henry IV, Part $2^{1}$}

The sexual propensity rules assume that sex-crime perpetrators are not only recidivists, but particularly aberrational, singularly dangerous, and essentially incapable of being rehabilitated. The perpetrators' presumed inability to control their deviant desires makes them seem more animal than human. Irrespective of their age, their type of victim, or the amount of time they have stayed out of trouble, sex offenders remain perpetually menacing. As such, the thinking goes, they deserve to be treated differently and more harshly under the law, and different rules of evidence are justified.

Yet, what if the above claims are false? What if sex offenders are not necessarily the compulsive offenders that politicians and the general public believe them to be? This paper refutes the assumptions about the nature of perpetrators and examines the effect of those assumptions on the creation and application of evidence law. Rather than merely presuppose that sex crime perpetrators are sick individuals who are driven to commit and recommit the same horrific crimes, we turn to scientific studies to learn what the research actually indicates.

Part II begins by discussing the history and traditional justifications for Rules 413-414. Part III focuses on the widespread assumption by rulemakers and judges that prior sex crimes are particularly probative for determining guilt. Part IV demonstrates that the psychological and criminological research on sex offenders does not support the high probative value assigned to prior bad acts in sex cases. It focuses in particular on recidivism, the effect of age on dangerousness, and the risks that different types of offenders pose. It concludes that the overbroad propensity rules are not justified by the empirical data. Part $V$ discusses the ability to predict dangerousness and asserts that based on the accused's prior sex crimes alone, judges and juries cannot effectively determine whether an accused offender is likely to reoffend. Although we disapprove of Rules 413-414 on many grounds, we are realistic that these rules and their state law analogs are here to stay. As such, Part VI offers specific advice to judges regarding how, particularly in close cases and when the prior bad acts occurred long ago, judges

1. William Shakespeare, The Second Part of King Henry IV, act 5, sc. v. 
should use their broad discretion when admitting such propensity evidence.

\section{Sexual Propensity Rules IN the United States}

\section{A. The Traditional Rule Against Character Evidence}

The traditional Anglo-American rule prohibits circumstantial use of character evidence, known as "propensity" evidence, whereby evidence of a person's particular characteristic or trait is offered to argue that the person acted in conformity with that trait or characteristic. ${ }^{2}$ For example, the prosecution cannot use evidence that the accused is an alcoholic to argue that she probably drove drunk on a particular occasion. In the same vein, specific-act evidence that the accused had a prior conviction for driving while intoxicated would also be inadmissible to prove the accused's propensity to drink and drive. ${ }^{3}$

With the exception of questioning a witness' character for honesty, the rule against using character evidence to prove behavior on a particular occasion is absolute in civil cases. ${ }^{4}$ In criminal cases, however, discrete exceptions have arisen where the accused may choose to assert his own good character or the bad character of the victim (and the prosecutor may rebut the same). ${ }^{5}$

Similarly, Rule 404(b) prohibits the use of other crimes, wrongs, or acts to prove propensity. It also clarifies, however, that specific acts can be admitted for other legitimate, non-propensity purposes, even when those acts may have some character overtones. Rule 404(b) provides examples of use of specific-act evidence, such as evidence proving knowledge, motive, intent, or plan. Such evidence is permissible because it is not offered to prove propensity, but rather is independently

2. FED. R. EVID. 404(a) provides in pertinent part: "Evidence of a person's character trait is not admissible to prove that on a particular occasion the person acted in accordance with the character or trait."

3. FED. R. EVID. 404(b) provides in pertinent part: "Evidence of a crime, wrong, or other act is not admissible to prove a person's character in order to show that on a particular occasion the person acted in accordance with the character."

4. Exceptions to the propensity rule exist for impeaching witnesses in both civil and criminal cases. In questioning witnesses or challenging their credibility generally, evidence may be adduced that focuses on the character for truthfulness of the witness. See FED. R. EVID. 608 . Rule 609 governs impeachment of witnesses with prior convictions. Very rarely is character itself an issue (such as the defense of truth in a defamation case) and then character is offered not for propensity but as an element of the case. See FED. R. EVID. 405(b).

5. FED. R. EVID. 404(a). Even where admissible, such character evidence is only provable through reputation or opinion evidence, which tends to be very general, and not through evidence of specific acts that would illustrate the propensity. On cross examination, character witnesses may be asked about specific instances, but only to test the witnesses' knowledge or to question their judgment, not to prove something about the character in question. FED. R. EVID. 405(a). 
relevant for another legitimate purpose. ${ }^{6}$

Traditionally, character evidence has been deemed objectionable because it is tangential, unfairly prejudicial, and unreliable. Objections arise from psychological questions surrounding the reliability of character evidence, particularly the way such evidence is generated in a courtroom. ${ }^{7}$ People are not predictable characters and so psychologists question whether we can reliably determine how someone behaved on one particular occasion by reviewing the person's past deeds. ${ }^{8}$

Even if past deeds or proclivities of character are logically relevant, character evidence is still objectionable because whatever little probative value it possesses may be outweighed by the dangers of unfair distraction, prejudice, or confusion. Character evidence is often only minimally related to the trial issues but is nonetheless diverting-the jury may become bogged down in the proof of character and become confused regarding the issues in the case. ${ }^{9}$ The character ban also reflects the concern that the jury may misuse the evidence by overvaluing its persuasiveness. They will take what is essentially a weak circumstantial argument-" "he did it once, he probably did it again," or "he's the type of person who would do such a thing"-and prove too much with it. ${ }^{10}$ Finally, and most importantly, jurors may be

6. Roger Park, David Leonard, Aviva A. OREnSten \& Stephen Goldberg, Evidence LAW: A STUDENT's GUIDE TO THE LAW OF EVIDENCE AS APPLIED IN AMERICAN TRIALS 162 (3d ed. 2011). The examples listed in 404(b) are not exhaustive. See id. ("The list of purposes for which other crimes may be offered is a time-honored (though non-exclusive) one."); see generally EDWARD J. IMWINKELRIED, UNCHARGED MISCONDUCT EVIDENCE (1984). Courts and prosecutors have been quite creative in articulating non-propensity reasons for admitting evidence under 404(b). See supra note 4.

7. For an assessment of the psychological value of character evidence, see Miguel Angel Mendez, California's New Law on Character Evidence: Evidence Code Section 352 and the Impact of Recent Psychological Studies, 31 U.C.L.A. L. REV. 1003, 1044-59 (1984). See also David P. Bryden \& Roger C. Park, "Other Crimes" Evidence in Sex Offense Cases, 78 MINN. L. REV. 529, 561-62 (1994); Edward J. Imwinkelried, Reshaping the "Grotesque" Doctrine of Character Evidence: The Reform Implications of the Most Recent Psychological Research, 36 Sw. U. L. REV. 741 (2008); David P. Leonard, The Use of Character to Prove Conduct: Rationality and Catharsis in the Low of Evidence, 58 U. COLO. L. REV. 1, 42-45 (1986).

8. See generally Susan M. Davies, Evidence of Character to Prove Conduct: A Reassessment of Relevancy, 27 CRIM. L. BULL. 504, 511-33 (1991).

9. If the trait or other similar act is contested, much valuable court time can be frittered away proving the character question. Therefore, administrative concerns about the waste of time and the cumulative nature of character evidence also contribute to the general disfavor of character evidence. This concern echoes the principles of Rule 403, which provides that relevant evidence may be excluded if its probative value is substantially outweighed by its unfair prejudice, capacity to distract or confuse, or its potential to waste time. FED. R. EVID. 403.

10. "The natural and inevitable tendency of the tribunal ... is to give excessive weight to the vicious record of crime ...." 1 JOHN HENRY WIGMORE, A TREATISE ON THE ANGLO-AMERICAN SYSTEM OF EVIDENCE IN TRIALS AT COMMON LAW $§ 194$ (3d ed. 1940). The worry is that jurors will be overly swayed by prior similar acts and that jurors' reasoning facilities will be clouded. In Michelson $v$. United States, 335 U.S. 469 (1948), Justice Jackson explained:

Courts that follow the common-law tradition almost unanimously have come to disallow resort by the prosecution to any kind of evidence of a defendant's evil character to 
outraged by the conduct or trait. They may grow to detest the accused or unconsciously desire to punish the person about whom the character evidence is offered to make him pay for previous misconduct. ${ }^{11}$ Jurors who feel this way might ignore the standard of proof or at least fret less over reasonable doubt. Whereas they might have agonized over the possibility of convicting an innocent person, hearing that the accused committed similar bad acts might make jurors less cautious. ${ }^{12}$ At the very least, jurors' consciences are eased because they know that the defendant is not a blameless character.

\section{B. Current Sexual Propensity Rules in Federal Courts and the States}

\section{Federal Rules of Evidence 413-414}

Federal Rules of Evidence 413-415 allow the prosecutor to introduce the accused's prior similar acts in rape and child molestation cases. ${ }^{13}$ They provide that in criminal cases of sexual assault, "the court may admit evidence that the defendant committed any other sexual assault. The evidence may be considered on any matter to which it is relevant." ${ }^{, 14}$ This means that past instances may be used to make the generally

establish a probability of his guilt. Not that the law invests the defendant with a presumption of good character ... but it simply closes the whole matter of character, disposition and reputation on the prosecution's case-in-chief. The State may not show defendant's prior trouble with the law, specific criminal acts, or ill name among his neighbors, even though such facts might logically be persuasive that he is by propensity a probable perpetrator of the crime. The inquiry is not rejected because character is irrelevant; on the contrary, it is said to weigh too much with the jury and to so overpersuade them as to prejudge one with a bad general record and deny him a fair opportunity to defend against a particular charge. The overriding policy of excluding such evidence, despite its admitted probative value, is the practical experience that its disallowance tends to prevent confusion of issues, unfair surprise and undue prejudice.

Id. at 475-76 (citations and footnotes omitted).

11. See Old Chief v. United States, 519 U.S. 172, 180-81 (1997) (discussing "improper grounds" for juror decision making, including "generalizing a defendant's earlier bad act into bad character and taking that as raising the odds that he did the later bad act now charged (or, worse, as calling for preventive conviction even if he should happen to be innocent momentarily)") (quoting States v. Moccia, 681 F.2d 61 (1st Cir. 1982)); Moccia, 681 F.2d at 63 ("Although ... "propensity evidence' is relevant, the risk that a jury will convict for crimes other than those charged-or that, uncertain of guilt, it will convict anyway because a bad person deserves punishment-creates a prejudicial effect that outweighs ordinary relevance.").

12. See D. Craig Lewis, Proof and Prejudice: A Constitutional Challenge to the Treatment of Prejudicial Evidence in Federal Criminal Cases, 64 WASH. L. REV. 289, 326 (1989) (describing "diminished regret about possible error in a determination of guilt when the fact finder learns that the accused is an "evil person").

13. FED. R. EVID. 413; Violent Crime Control and Law Enforcement Act of 1994, Pub. L. No. 103-322, 108 Stat. 1796 (1994). We discuss only Rules 413-414, the criminal rules, and do not address Rule 415, which deals with sexual propensity in civil cases.

14. FED. R. EVID. 413-414; § 320935(a), 108 Stat. 1796. 
forbidden propensity argument that if the accused raped a woman once before, he has the character of a rapist and probably committed the rape charged. ${ }^{15}$ The evidence adduced has to pass the Huddleston standard, ${ }^{16}$ under which a judge must find that the jury could believe that the uncharged misconduct occurred. ${ }^{17}$ There is no time limit on when the prior bad act took place. ${ }^{18}$ Scholars agree that admission of such priorbad-acts evidence increases conviction rates. ${ }^{19}$

\section{State Adoptions of Analogous Rules}

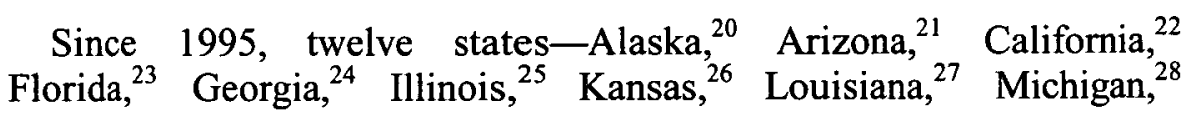

15. The proposed rules do not admit all character evidence or all arguably relevant specific wrongs, but are limited instead to evidence of the same type of criminal offenses as those with which the accused is formally charged. Rules $413-414$ also include a notice requirement. The prosecutor must disclose in advance any evidence of the uncharged offenses to the defendant, including statements of witnesses or a summary of the substance of any testimony that will be offered. A related approach rests on the doctrine of chances, which posits that it is inherently improbable that a person whose prior acts show that he is in fact a rapist or a child molester would have the bad luck to later be accused falsely of the same type of crime unless he was truly guilty. See generally Edward J. Imwinkelried, An Evidentiary Paradox: Defending the Character Evidence Prohibition by Upholding a Non-Character Theory of Logical Relevance, the Doctrine of Chances, 40 U. RiCH. L. REV. 419, 433 (2006). As a strictly statistical proposition, what are the chances various separate victims independently made the same false allegation? We note that false accusations would more likely involve someone who already is known to have committed a prior act of sexual misbehavior.

16. Huddleston v. United States, 485 U.S. 681 (1988).

17. Id. at 690 ; see also United States v. Enjady, 134 F.3d 1427 (10th Cir. 1998) (applying Huddleston to Rule 413).

18. "No time limit is imposed on the uncharged offenses for which evidence may be admitted; as a practical matter, evidence of other sex offenses by the defendant is often probative and properly admitted, notwithstanding very substantial lapses of time in relation to the charged offense or offenses." 140 CONG. REC. 23603 (daily ed. Aug. 21, 1994) (remarks of Rep. Molinari) (citations omitted); see also 137 CONG. REC. 3242 (daily ed. Mar. 13, 1991) (similar points in Senate sponsors' statement).

19. See Miguel A. Mendez \& Edward J. Imwinkelried, People v. Ewoldt: The California Supreme Court's About-Face on the Plan Theory for Admitting Evidence of an Accused's Uncharged Misconduct, 28 LOY. L.A. L. REV. 473, 474 (1995) (citing various studies and empirical evidence that jurors are highly persuaded by evidence of the accused immoral conduct).

20. AlASKa R. Evid. 404(b)(2)-(3).

21. ARIZ. R. EVID. 404(c).

22. CAL. EVID. CODE $\S 1108$ (West 2003). California has a special jury instruction, CALJIC No. 2.50.01. If the jury finds that the accused committed a prior sexual offense, it may (but is not required to) infer that the accused has a disposition to commit sexual offenses. A prior offense is not sufficient by itself to prove beyond a reasonable doubt that the accused committed the charged crimes. Any inference was simply one item for the jury to consider along with all the other evidence. People $v$. Burch, 2012 WL 1859669 (Cal. Ct. App. 2012).

23. Fla. Stat. ANN. $\S 90.404(2)(b)-$ (c) (West 2011 ).

24. GA. CODE. ANN. $\$ 24-4-413$ (2013). Georgia added Rules $413-414$ by adopting the Federal Rules of Evidence in toto. See Joy Lukachick, Georgia Bill Alters Rules on Evidence, TIMES FREE PRESS (Dec. 26, 2010), http://www.timesfreepress.com/news/2010/dec/26/georgia-bill-alters-rules-onevidencel. 
Nebraska, ${ }^{29}$ Texas, ${ }^{30}$ and $\mathrm{Utah}^{31}$-have adopted statutes similar to Rules 413 and 414 . Of the states that have passed special statutes, some (Florida, Illinois, Louisiana, Missouri, Michigan, and Texas) have limited their attention to child victims of sexual abuse. A few states (Florida, Nebraska, and Illinois) also impose the higher burden of clear and convincing evidence for demonstrating that the uncharged misconduct occurred. ${ }^{32}$ Some students and scholars have advocated for other states to jump on the bandwagon and add propensity rules for sex crime. $^{33}$ Five states-Delaware, Indiana, Iowa, Missouri and Washington-passed similar legislation, but their Supreme Courts rejected the rules as unconstitutional. ${ }^{34}$

\section{725 ILl. COMP. Stat. ANN. 5/115-7.3 (West 2011). \\ 26. KAN. STAT. ANN. § 21-5502 (2011). \\ 27. LSA-C.E.Art 412.2 (West 2004). \\ 28. MICH. COMP. LAWS ANN. § 7668.27a (West 2004).}

29. NEB. REV. STAT. § 27-412 (2010) (explicitly mandating Rule 403 balancing, requiring clear and convincing evidence that the accused actually committed the prior act or acts of sexual assault); See also John Matson, Huskers Jump on Congress's Fumble: Nebraska Rules of Evidence 413-15 Correct the Facial Deficiencies of Federal Rules of Evidence 413-15, 45 CREIGHTON L. REv 277 (discussing the 2010 change to Nebraska law adopting a version of the federal propensity rules).

30. TEX. CRIM. Proc. Code ANN. § 38.37 (Vemon Supp. 2004).

31. UTAH R. EVID. 404(c).

32. Uncharged misconduct is a term of art. In fact, such conduct may have been charged in the past, but the other wrongs crimes or acts denoted as uncharged misconduct are not the subject of a criminal charge for which they are being offered as propensity evidence. See generally IMWINKELRIED, supra note 6.

33. See, e.g., William E. Marcantel, Note, Protecting the Predator or the Prey? The Missouri Supreme Court's Refusal to Allow Past Sexual Misconduct as Propensity Evidence, 74 Mo. L. REV. 211 (2009) (criticizing the Missouri Supreme Court for striking down legislative attempts to adopt state rules similar to Rules 413-414); Jessica D. Kahn, Note, He Said, She Said, She Said: Why Pennsylvania Should Adopt Federal Rules of Evidence 413 and 414, 52 VILL. L. REV. 641 (2007); Joyce R. Lombardi, Comment, Because Sex Crimes Are Different: Why Maryland Should (Carefully) Adopt the Contested Federal Rules of Evidence 413 and 414 that Permit Propensity Evidence of a Criminal Defendant's Other Sex Offenses, 34 U. BALT. L. Rev. 103 (2004); Michelle Harper Lawson, Note, Federal Rules of Evidence 413 and 414: A Guide for Massachusetts Evidentiary Law, 37 SUFFOLK U. L. REV. 1175 (2004); Lisa M. Segal, Note, The Admissibility of Uncharged Misconduct Evidence in Sex Offense Cases: New Federal Rules of Evidence Codify the Lustful Disposition Exception, 29 SUFFoLK U. L. REV. 515 (1995) (advocating that Rhode Island adopt Rules 413-15).

34. See State v. Gresham, 269 P.3d 207, 210 (Wash. 2012) ("[B]ecause RCW 10.58.090 [an analog to Rules 413-414] irreconcilably conflicts with ER 404(b) and governs a procedural matter, we hold that its enactment violates the separation of powers doctrine and that the statute is, accordingly, unconstitutional."); State v. Cox, 781 N.W.2d 757, 768 (Iowa 2010) ("Based on Iowa's history and the legal reasoning for prohibiting admission of propensity evidence out of fundamental conceptions of faimess, we hold the lowa Constitution prohibits admission of prior bad acts evidence based solely on general propensity."); State v. Ellison, 239 S.W.3d 603, 607-08 (Mo. 2007) (en banc) (striking down section 566.025 of the Missouri Revised Statutes as violating the Missouri Constitution and the court's prohibition against propensity evidence) ("Missouri constitution prohibits the admission of previous criminal acts as evidence of a defendant's propensity .... Evidence of a defendant's prior criminal acts, when admitted purely to demonstrate the defendant's criminal propensity, violates one of the constitutional protections vital to the integrity of our criminal justice system."). Similarly, the Indiana legislature passed rules similar to 413-414, BURNS IND. CODE ANN. §35-37-4-15, but the Indiana 


\section{State Common Law Approaches}

Several states have developed common law doctrines that apply special rules to character evidence in sex crimes, including Rhode Island and Washington's "lustful disposition" exceptions to Rule 404(b) ${ }^{35}$ Other states, including Colorado, Delaware, Kentucky, Maryland, Maine, Minnesota, Oklahoma, and Wisconsin, liberally extend the application of Rule 404(b) non-propensity purposes, or offer wider "latitude" in sexual assault cases. ${ }^{36}$ Some states do not acknowledge a liberalized standard, but clearly engage in one. ${ }^{37}$ In this respect it is fair

Supreme Court held the statutes to be a nullity because they conflicted with the evidence rules propounded by the Court, which has the exclusive right under the Indiana constitution to establish court rules, including the rules of evidence. See Day v. State, 643 N.E.2d 1 (Ind. Ct. App. 1994). Also, the Delaware Supreme Court on the recommendation of its appointed Permanent Advisory Committee on the Delaware Uniform Rules of Evidence has rejected Rules 413-414. See Thomas J. Reed, The ReBirth of the Delaware Rules of Evidence: A Summary of the 2002 Changes in the Delaware Uniform Rules of Evidence, 5 DEL. L. REV. 155, 166-75 (2002) (praising the Delaware Supreme Court for not adopting the rules); State v. Ellison, 239 S.W.3d 603, 607-08 (Mo. 2007) (en banc) ("In holding this statute unconstitutional, this Court acts consistently with a long line of cases holding that the Missouri constitution prohibits the admission of previous criminal acts as evidence of a defendant's propensity.").

35. See, e.g., State v. Greene, 823 A.2d 1129 (R.I. 2003); State v. Rice, 755 A.2d 137 (R.I. 2000); State v. Kilgore, 53 P.3d 974 (Wash. 2002); see Lannan v. State, 600 N.E.2d 1334 (Ind. 1992) (discussing the common-law lustful disposition); G. Adam Cossey, Comment, $A$ Dangerous Leap: The Admission of Prior Offenses in Sexual-Assault and Child Molestation Cases in Arkansas, 61 ARK. L. REV. 107 (2008) (critiquing the Arkansas common-law approach); Tamara Larsen, Sexual Violence Is Unique: Why Evidence of Other Crimes Should Be Admissible in Sexual Assault and Child Molestation Cases, 29 HAMLINE L. REV. 177 (2006) (discussing Minnesota's broad approach to Rule 404(b) nonpropensity purposes in child abuse cases).

36. For instance, the Maryland common law exception admits evidence to show the accused's propensity for illicit sexual relations, but only of the same type and with the same victim. Maryland requires a clear and convincing standard for uncharged misconduct. See Thompson v. State, 988 A.2d 1011, 1014 (Md. 2010) (citing Vogel v State, 315 Md. 458, 554 (1989)). Colorado specifically extends the use of Rule 404(b) by statute:

The prosecution may introduce evidence of other acts of the defendant to prove the commission of the offense as charged for any purpose other than propensity, including: Refuting defenses, such as consent or recent fabrication; showing a common plan, scheme, design, or modus operandi, regardless of whether identity is at issue and regardless of whether the charged offense has a close nexus as part of a unified transaction to the other act; showing motive, opportunity, intent, preparation, including grooming of a victim, knowledge, identity, or absence of mistake or accident; or for any other matter for which it is relevant. The prosecution may use such evidence either as proof in its case in chief or in rebuttal, including in response to evidence of the defendant's good character.

COLO. REV. STAT. ANN. §16-10-301 (3).

37. See, e.g., Jill C. Legg, State v. Ondricek: Admission of Prior Bad Acts-The Exception or the Rule?, 42 S.D.L. REv. 165, 165 (1997) (discussing a South Dakota Supreme Court case in which a twenty-year-old rape was admitted to prove intent and common scheme or plan and arguing that the broad admission under South Dakota's version of Rule 404(b) creates a "danger of overwhelming the general rule of exclusion"). Even among the states that appear to retain a prohibition on propensity evidence, the new federal rules have been influential. See, e.g., Hart v. State, 57 P.3d 348, 353 n.3 (Wyo. 2002) (admitting prior uncharged misconduct not to show propensity, but for plan, modus 
to say that the ban on character evidence has never been, from a functional standpoint, absolute. Finally, many states make no particular exception for prior sexual misconduct and treat it the same as any other type of misconduct analyzed under Rule 404(b) or the state equivalent. ${ }^{38}$

\section{Justifications for Special Rules Relating to Sex Crimes}

Scholars and jurists debate the fairness of character evidence concerning sexual propensity, particularly evidence of other bad acts. ${ }^{39}$ Prior sex-crime evidence used to show propensity can be invasive and staggeringly prejudicial. It is objectionable for all the traditional reasons that underlie the common-law ban on propensity evidence. Recent psychological evidence reinforces the proposition that the accused faces insurmountable prejudice when the jury learns of his prior sex crimes. Polling indicates that Americans express more concern about child molestation than any other danger to the community, ${ }^{40}$ so someone with a prior sex crime may seem particularly dangerous. Ironically, these sentiments exist even though the number of sex crimes has decreased by every major measure for the past twenty years. ${ }^{41}$ Additionally,

operandi, and identity, and specifically citing Federal Rules of Evidence 413-15 to substantiate the decision).

38. See, e.g., State v. McFarland, 721 S.E.2d 62, 77 (W. Va. 2011) (Davis, J., dissenting) (critiquing the majority's refusal to admit prior defendant's sexual conduct as evidence of motive or plan and noting that "the majority's rejection of the admission of the evidence, and its application to future cases, will now allow serial rapists to be paraded in front of juries as All-American boy scouts.").

39. See, e.g., 23 Charles alan Wright \& KenNeth W. Graham, JR., FEderal Practice AND PROCEDURE §§ 5411-16, 5411A-17A (Supp. 2012); James Joseph Duane, The New Federal Rules of Evidence on Prior Acts of Accused Sex Offenders: A Poorly Drafted Version of a Very Bad Idea, 157 F.R.D. 95, 114-15 (1994); Margaret C. Livnah, Branding the Sexual Predator: Constitutional Ramifications of Federal Rules of Evidence 413 Through 415, 44 CLEV. ST. L. REV. 169, 181 (1996) (noting the increased risk of due process violation because juries may be prejudiced by explicit reference to prior bad sexual acts); Dale A. Nance, Foreword: Do We Really Want to Know the Defendant?, 70 CHI.-KENT L. REV. 3 (1994) (summarizing various arguments against the sexual propensity rules); Louis M. Natali, Jr. \& R. Stephen Stigall, "Are You Going to Arraign His Whole Life? ": How Sexual Propensity Evidence Violates the Due Process Clause, 28 LoY. U. CHI. L.J. 1, n.34 (1996); Aviva Orenstein, No Bad Men!: A Feminist Analysis of Character Evidence in Rape Trials, 49 HaStings L.J. 663 (1999); Myrna S. Raeder, American Bar Association Criminal Justice Section Report to the House of Delegates, reprinted in 22 FORDHAM URB. L.J. 343 (1995); Mark A. Sheft, Federal Rule of Evidence 413: A Dangerous New Frontier, 33 AM. CRIM. L. REV. 57, 82 (1995) ("Rule 413 erodes the presumption of innocence in violation of the Fifth Amendment's Due Process Clause.").

40. Between Apr. 19, 2005 and May 1, 2005 a poll sponsored by CNN/USA Today and Gallup asked respondents the degree to which they were concerned about various events occurring in their community-a question that did not specifically refer to the likelihood of the different events. Leading the list was sexual molestation of children, followed by sale or use of methamphetamine, use or sale of cocaine, violent crime, and then acts of terrorism. Joseph Carroll, Crystal Meth, Child Molestation Top Crime Concerns, GALLUP (May 3, 2005), http://www.gallup.com/poll/16123/crystal-meth-child-molesta tion-top-crime-concerns.aspx.

41. According to the Uniform Crime Reports, data compiled by the FBI from law enforcement agencies across the country, the forcible rape rate in the United States has dropped $36 \%$ from 1992 to 
Americans think that child molesters are less likely to be rehabilitated than perpetrators of other violent crimes, a reason to convict and throw away the key. ${ }^{42}$ Such counterfactual beliefs and negative stereotypes will lead to loathing the accused and wishing to prophylactically confine anyone who has committed a past sex crime; hence, the unfair prejudice of informing jurors of prior sex crimes is severe.

This Article, however, does not rehash the trenchant critique that explains why the highly prejudicial sexual propensity rules are a terrible idea. Plenty of excellent scholarship already exists on that point, and the evidence establishment, both the professoriate ${ }^{43}$ and the rulemakers, ${ }^{44}$

2010. Uniform Crime Reports, FBI, http://www.fbi.gov/about-us/cjis/ucr/crime-in-the-u.s/2010/crimein-the-u.s.-2010/tables/10tbl01.xls (last visited Aug. 1, 2012). According to the National Crime Victimization Survey (NCVS), rapes and sexual assaults have been dropping as well. National Crime Victimization Survey Resource Guide, NAT'L ARCHIVE CRIM. JUST. DATA, http://www.icpsr.umich.edu/ icpsrweb/NACJD/NCVS/. Between 1993 and 2010, the number of reported rapes and sexual assaults dropped $40 \%$-from 312,580 to 188,380 . See Craig Perkins, Patsy A. KLAUS, Lisa D. Bastian \& ROYN L. COHEN, U.S. DePARTMENT OF JUSTICE, CRIMINAL VictimizATION IN THE UNITED STATES, 1993, at 9 (1993). The National Child Abuse and Neglect Data System (NCANDS), which aggregates and publishes statistics from child protection agencies across the country, including all fifty states, the District of Columbia, and Puerto Rico, found that sexual abuse of children has dropped 58\% from 1992 to 2008. DAVID FINKELHOR, LISA JONES \& ANNE ShatTUCK, UPDATEd TRENDS IN CHILD MALTREATMENT, 2008 1-2 (2010).

42. Half the 2005 sample was asked, "Just your best guess, do you think people who commit the crime of child sexual molestation are more likely or less likely to be successfully rehabilitated than people who commit other serious crimes?" $8 \%$ said more likely and $77 \%$ said less. Interestingly, more people in the April 2005 study seemed to believe in the possibility of rehabilitation than in a similar study conducted fourteen years earlier. The Star Tribune National Poll interviewed 1,101 participants between Aug. 6 and Aug. 25, 1991. These participants were asked:

Now some questions about people convicted of sex offenses such as rape, sexually abusing a child or incest. Do you agree or disagree that most sex offenders continue to repeat their crimes no matter what the punishment? (If agree/disagree ask: Do you feel strongly or not so strongly about that?)

$78 \%$ agreed strongly, $9 \%$ agreed not strongly, 3\% disagreed not strongly, $4 \%$ disagreed strongly, and $7 \%$ didn't know. AVIVA A. ORENSTEIN, EMPIRICAL FallaCies of EVIDENCE LAW: A CRITICAL LOOK AT AdMission OF Prior SeX CRIMES 13 (2012) (reviewing Star Tribune National Poll, 8/6/91-8/25/91, Question 13).

43. In a letter to Judge Ralph K. Winter, Jr., Chair of the Advisory Committee on Evidence Rules, a group of law professors expressed concem over numerous ambiguities including questions concerning the discretion of the trial judge and the interaction with other rules concerning hearsay, best evidence, and limitation on impeachment of witnesses. See David P. Leonard, The Federal Rules of Evidence and the Political Process, 22 FoRDHAM URB. L. J. 305, 335 (1995) (quoting and discussing the letter).

44. The Advisory Committee on Evidence of the Federal Judicial Center made the following comments on Rules 413-414, which bypassed the regular rule-making process:

Furthermore, the new rules, which are not supported by empirical evidence, could diminish significantly the protections that have safeguarded persons accused in criminal cases and parties in civil cases against undue prejudice. These protections form a fundamental part of American jurisprudence and have evolved under long-standing rules and case law. A significant concern identified by the committee was the danger of convicting a criminal defendant for past, as opposed to charged, behavior or for being a bad person. 
have made no secret of their opposition to the approach heralded by Rules $413-414$ on the grounds that it is wildly unfair. For reasons of unfair prejudice and lack of due process, five state supreme courts have rejected these rules. ${ }^{45}$

Instead, rather than attacking the unfair prejudice engendered by Rules 413-414, we question the basic premise of these Rules. Many critiques of these Rules and their state analogs begin by conceding the probative value of the evidence and then focus on the extreme prejudice it engenders. We, however, marshal the empirical evidence and focus our challenge to these Rules' validity notwithstanding the unfairness they engender.

Proponents primarily justify these rules in three ways. First, they argue that there is something particularly difficult about proving sex crimes. This argument points to the special need for other-act evidence because without it, the jurors cannot be convinced to convict. Sex crimes usually occur without witnesses other than the perpetrator and the victim; often there is no definitive physical evidence of the crime. Even when such physical evidence exists, a delay in reporting may make collection impossible. ${ }^{46}$ The trial becomes a swearing match between the alleged perpetrator and the alleged victim. ${ }^{47}$ In the case of Rule 413, which involves rape of adults, the accused will often argue consent, and the jury is apt to believe various rape myths that may lead jurors to believe that the victim was "asking for it" or consented and then later lied about the encounter. ${ }^{48}$ Jurors themselves may be in denial about the

JudiClal CONFERENCE of THE U.S., Report Of The Judicial Conference On The Admission Of Character Evidence in Certain Sexual Misconduct Cases, 159 F.R.D. 51, 52-53 (1995) (submitted pursuant to section 320935 of the Violent Crime Control and Law Enforcement Act of 1994, Pub. L. No. 103-322 (1994)).

45. See supra note 34 and accompanying text.

46. See David P. Leonard, Character and Motive in Evidence Law, 34 LoYOLA L. REV. 439, 490 (2001) (" $[E]$ ven if physical evidence did exist at one time, it often has been destroyed by the time the crime is reported and investigated."); Matson, supra note 29, at 282 (quoting proponents of Nebraska's new rule that "[sex] offenses result in long-lasting and serious harm to the affected individual" they "are often not reported or are reported long after the offense took place, and that typically there are no witnesses to these offenses except for the accused and the victim. For these reasons, there is often no evidence of the assault, except for the conflicting testimony of the victim and the accused") (footnotes omitted).

47. Reneta Lawson Mack, A LAYPERSON'S GuIDE TO CRIMINAL LAW 77 (Greenwood Publishing Co. 1999) ("Therefore, the typical rape trial becomes a contest of credibility. Who is more credible-the victim or the defendant? Which version of events is more believable?"). As Representative Molinari explained, "Sexual assault and child molestation do not ordinarily occur in the presence of multiple credible witnesses. The Rules of Evidence need to be changed to improve the ability of prosecutors to obtain convictions against the perpetrators of such crimes." Representative Susan Molinari, Remarks to the House of Representatives on Proposed Amendment to the Federal Rules of Evidence in Cases of Sexual Assault and Child Molestation (Oct. 22, 1991).

48. Rape myths are a "prejudicial, stereotyped or false beliefs about rape, rape victims, and rapists." The rape myth includes attitudes and beliefs that are used in order to justify male sexual 
prevalence of acquaintance rape. ${ }^{49}$ Rule 413 addresses the maddening problem of repeat offenders who manage to discredit each survivor individually. ${ }^{50}$ In the case of Rule 414 , involving children, the accused will often argue that the child is vengeful, confused, fanciful, or has been encouraged to fabricate accusations by an adult. ${ }^{51}$ The Rules, therefore, address the power imbalance between the victim and the accused. Additionally, because the standard for conviction is beyond a reasonable doubt, and the events are often embarrassing and shameful for the victim, without corroborative evidence a victim's testimony could seem tentative and unconvincing, leading to acquittal. Furthermore, even though jurors are sometimes explicitly instructed that one witness's testimony constitutes sufficient evidence to support a conviction, they may be uncomfortable rendering a guilty verdict (especially in a rape or child molestation case) without more evidence. In short, supporters emphasize the necessity of admitting prior sex crimes, arguing that without such evidence victims will not be believed and convictions cannot be won. ${ }^{52}$

A second set of arguments focuses on the victim, emphasizing both the special harm endured and the unique empowerment of helping to convict perpetrators. Some advocates believe that the unique nature of sex crimes, which cause a distinctive and devastating type of harm, ${ }^{53}$ demands special evidentiary treatment. Senator Kyl, a sponsor of Rules 413-414, noted that even when the victim is "too traumatized, intimidated, or humiliated to file a complaint and go through the full

violence against women. Sarah Theodore, Note, An Integrated Response to Sexting: Utilization of Parents and Schools in Deterrence, 27 J. CONTEMP. HEALTH L. \& POL'y 365, n.53 (2011) (citing Janet Anderson, Rape Myths: Letters from the Editor, 9 RESEARCH \& ADVOCACY DIGEST 1 (2007), available at http:/www.wcsap.org/advocacy/pdf/rapemyths0507.pdf); Morrison Torrey, When Will We Be Believed? Rape Myths and the Idea of a Fair Trial in Rape Prosecutions, 24 U.C. DAVIS L. REV. 1013 (1991); Francis X. Shen, How We Still Fail Rape Victims: Reflecting on Responsibility and Legal Reform, 22 COLUMB. J. GENDER \& L. 1 (2011).

49. See Orenstein, supra note 39 , at 692 .

50. See id. at 679-80.

51. See, e.g., United States v. Enjady, 134 F.3d 1427 (10th Cir. 1998). Children, however, cannot consent to molestation, even if they don't resist or might have enjoyed the encounter. Kenneth V. Lanning, Compliant Child Victims: Confronting an Uncomfortable Reality, in VIEWING CHILD PORNOGRAPHY ON THE INTERNET (2005), available at hitp://www.denreed.com/documentts/6bComplia ntChildVictimsLanning2005.pdf.

52. As Senator Robert Dole explained of the new rules: "[E]vidence of this type is frequently of critical importance in establishing the guilt of a rapist or child molester, and . . concealing it from the jury often carries a grave risk that such a criminal will be turned loose to claim other victims." 137 CONG. REC. S9081 (daily ed. Apr. 24, 1991).

53. See Lucy Berliner, Sex Offenders: Policy and Practice, 92 Nw. U. L. REv. 1203, 1206 (citing research regarding the long-lasting negative effects associated with sexual assault, which causes greater psychological harm to victims than do other crimes, including causing PTSD, affecting the sexual behavior of child victims and the sexual functioning of adult rape victims and adult interpersonal relationships). 
procedure of a criminal prosecution," such victims "are often willing to bear the burden of testifying when they find out that the person who marred their lives has also victimized others." 54

In sum, allowing the jurors to consider the accused's similar prior bad acts and his character for sexual deviance will increase conviction rates and imprisonment, thereby protecting and empowering vulnerable populations. Arguably, introducing evidence of the accused's prior bad conduct would also sensitize our society to the prevalence of sex crimes and empower victims. ${ }^{55}$ The increased rate of prosecution and conviction would promote general deterrence, illuminating the widespread problem of sexual violence and signaling our seriousness about addressing sex crimes.

The problem with the above arguments is that they advocate changing the rules of the game at the expense of the accused merely because the alleged harm is so egregious and the crime so difficult to prove. ${ }^{56}$ The two arguments above are based on raw need and cannot withstand a presumption of innocence; they cannot serve as a principled justification for departing from the evidence traditional ban on propensity. In the next Part, however, we examine a final, central argument concerning the probative value of sexual propensity evidence: that such prior bad acts are particularly probative because sex crimes are highly recidivistic.

\section{EVIDENCE LAW'S MisTaKen PSYCHOLOGICAL UNDERSTANDINGS OF AND ASSUMPTIONS ABOUT SEX CRIMES AND THEIR PERPETRATORS}

Proponents of admitting evidence of propensity in sex crimes focus on the purportedly unique aspects of the alleged perpetrators. Those who favor special evidence rules for prior sex crimes justify this treatment based on their perceptions of perpetrators. They rely on three related claims about the psychological makeup of perpetrators: (1) perpetrators are deviant, antisocial, remorseless individuals; ${ }^{57}(2)$ they are highly recidivistic; and (3) the sexual perversions prompting these

54. 140 CONG. REC. H7334 (daily ed. Apr. 13, 994).

55. Also, Rules $413-414$ and their state analogs arguably allow victims to speak out in confidence, knowing that they will be supported in their assertions and thus more likely to be treated with respect by the jury. Senator Kyl, a sponsor of Rules $413-414$, argued that they would "go a long way toward neutralizing the psychological damage a rape victim often experiences going through the judicial process." Id.

56. See Leonard, supra note 46, at 490 ("[C]ourts have long approved admission of such evidence in sex crime cases for at least three reasons, all of which tend toward the same conclusionthat proof of the crime's occurrence is exceedingly difficult to muster .... At base, then, courts have admitted the uncharged misconduct evidence in these cases because it is needed.").

57. Rivera v. Rivera, 262 F. Supp. 2d 1217, 1226 (D. Kan. 2003) (noting that a history of molestation is "exceptionally probative" in showing "an unusual disposition" that "does not exist in ordinary people”). 
crimes cannot be cured. ${ }^{58}$ These unique qualities brand sex offenders as fiends, unalterably different from average people for whom propensity rules are necessary and justified.

\section{A. Deviance}

David Karp, a former lawyer in the Justice Department and chief architect and defender of the Federal Rules 413-415, argued that "[o]rdinary people do not commit outrages." 59 Karp emphasized the probative value of character evidence about an accused who committed similar acts, contending that "evidence showing that the defendant has committed sexual assaults on other occasions places him in a small class of depraved criminals, and is likely to be highly probative in relation to the pending charge." 60 This central assumption about perpetrators of sex crimes-that they are a deviant, discrete group of outsiders and psychopaths-justifies the sex propensity rules and encapsulates their faulty psychological, statistical, and sociological presumptions.

The legislative history of Rules $413-414$ is replete with commentary - one even might say findings--that those who commit sex crimes are truly deviant and thus utterly different from normal citizens. ${ }^{61}$ For instance, Representative Molinari stated, "[A] history of [child molestation in a defendant] tends to be exceptionally probative because it shows an unusual disposition of the defendant-a sexual or sadosexual interest in children-that simply does not exist in ordinary people., 62

58. Treatment includes hormonal treatments ("chemical castration"), other drugs such as selective serotonin reuptake inhibitors, surgical castration, and psychotherapy. Ryan C.W. Hall \& Richard C.W. Hall, A Profile of Pedophilia: Definition, Characteristics of Offenders, Recidivism, Treatment Outcomes, and Forensic Issue, 82 MAYO CLINIC PROC. 457, 465-66 (2007). Hormonal treatments "work by suppressing testosterone levels." $I d$. at 466.

59. David J. Karp, Evidence of Propensity and Probability in Sex Offense Cases and Other Cases, 70 CHI.-KENT L. REv. 15, 20 (1994). Karp was senior counsel for the Office of Policy Development, United States Department of Justice. The ideas for new rules originated in the Department of Justice, and Karp was one of the original drafters. At least one court has confirmed that David Karp's article expanding on his address to the AALS carried the weight of legislative history, according to the sponsors of Rule 413. See Johnson v. Elk Lake Sch. Dist., 283 F.3d 138 (3d Cir. 2002).

60. Karp, supra note 59, at 24 (emphasis added).

61. Obviously not all Senators thought Rules 413-414 were a good idea. Then Senator Joseph Biden stated that "[i]t is a very dangerous amendment." 139 CONG. REC. 27550 (daily ed. Nov. 4, 1993). Realistically, however, he observed "that any amendment anyone would bring to the floor that has anything to do with child molestation or sexual offenses is likely to get 51 votes here, no matter what it is." Id. Biden further mused that "if we said in cases of sexual molestation of a child we should require the defendant to undergo electric shock treatment, we would probably get a vote for that here. We would probably get a vote for that here, because everybody is against those heinous crimes." Id.

62. 140 CONG. REC. 23603 (daily ed. Aug. 21, 1994); see also Tamara Larsen, Sexual Violence Is Unique: Why Evidence of Other Crimes Should Be Admissible in Sexual Assault and Child 
To fully understand and appreciate the lure of the sexual propensity rules, we must examine the narrative underlying rape and child molestation cases. ${ }^{63}$ In examining the cultural stories surrounding sex crimes we find a special, truly despicable role for the perpetrator. Supporters of Rules 413-414 argue that the probative value of the prior rapes is high because the sexual aggressiveness and proclivities of defendants are unique. In the area of adult rape, the prototypical "real" rape $^{64}$ is a tale of female chastity contrasted with uncontrollable, almost bestial male lust. ${ }^{65}$ The villain of this fable is a sadistic, sex-crazed, deviant, sociopathic loser who has no girlfriend. ${ }^{66} \mathrm{He}$ is violent and uses extreme force. ${ }^{67}$ There is the related myth that rapes are perpetrated primarily by strangers and that only rarely do acquaintances and intimates commit rape. ${ }^{68}$ The cultural paradigm is of strangers in both senses - unknown to the victim and just simply strange.

In a similar vein, the iconic child molester cannot control his deviant lustful urges and will offend repeatedly unless he is locked away

Molestation Cases, 29 HAMLINE L. REV. 177 (2006) (discussing Minnesota's broad approach to Rule 404(b) non-propensity purposes in child abuse cases).

63. Discussion of rape myths about victims is often used to justify Rules $413-415$ as balancing the scales because victims tend not to be believed. However, there are also myths about perpetrators (which in their own ways may be harmful to women as well). For instance, if all rapists are presumed to be creepy strangers, a fellow college student is less likely to be perceived as a "real rapist." See SUSAN ESTRICH, REAL RAPE (1987); see also Orenstein, supra note 39; Christina E. Wells \& Erin Elliott Motley, Reinforcing the Myth of the Crazed Rapist: A Feminist Critique of Recent Rape Legislation, 81 B.U.L. REV 127 (2001).

64. See ESTRICH, supra note 63; Orenstein, supra note 39.

65. See ANDrew TASlitz, RAPE AND THE Culture of THE COURTROOM (1999); N. Jermi Duru, The Central Park Five, the Scottsboro Boys, and the Myth of the Bestial Black Man, 25 CARDOzo L. REV. 1315 (2004).

66. The cultural paradigm includes a victim-ideally young, attractive, and respectable-who has been brutally attacked by a stranger. Elsewhere one of us has written about cultural expectations for the victim, who is chaste, cautious, and truthful, reports the attack immediately, and has no inconsistencies in her story. See Orenstein, supra note 39.

67. Some perpetrators benefit from the rape myth that "nice" (well educated, white, middle class, employed) men do not rape and that only men who cannot secure normal consensual sex resort to rape. See Mary I. Coombs, Telling the Victim's Story, 2 TEX. J. WOMEN \& L. 277, 281 (1993) ("Rapists are aggressive, uncouth, lower-class strangers, probably African-American or Hispanic."). Both Professor Andrew Taslitz and Professor Katharine Baker discuss the role of race and racism in rape culture. See TASLITZ, supra note 65; Katharine K. Baker, Once a Rapist? Motivational Evidence and Relevancy in Rape Law, 110 HARV. L. REV. 563, 589 (1997) (arguing that "Rule 413 and its supporting rationale fail to acknowledge, much less incorporate, most of what scholars have learned about rape in the past twenty-five years"). Torrey, supra note 48, at 1048. Similarly Professor Coombs quotes reactions to William Kennedy Smith's rape charge. One court watcher said, "I just find it hard to believe that someone with that much money would have to resort to rape to get what he wants." Coombs, supra, at 301 n.96.

68. James V. P. Check \& Neil M. Malamuth, Sex Role Stereotyping and Reactions to Depictions of Stranger Versus Acquaintance Rape, 45 J. PERSONALITY \& SOC. PSYCH. 344, 345 (1983). 
forever. ${ }^{69}$ High profile cases like the rape and murder of Polly Klaas ${ }^{70}$ and Megan Kanka ${ }^{71}$ create the picture of a predatory sex fiend who rapes and kills. The perpetrator is always male, and he is, like in the cultural story of rape, usually a stranger. When the victim knows him, the perpetrator is someone like a priest, an odd unattached male, or a sociopath in a position of trust and power who takes advantage of a position of trust to offend over and over again. ${ }^{72}$

\section{B. Recidivism: Powerless to Stop and Impossible to Cure}

Another related trope about sex-crime perpetrators is that they are highly recidivistic. As Representative Molinari explained, "Only in these two charges [rape and child molestation] would we extend these Federal rules of evidence, two charges, where there are no witnesses and no corroboration and where there is a record of repeat offending." 73 Representative Molinari quoted the National Institute of Mental Health, which she claimed offered the following statistic, that child molesters "molest children 117 times in their lifetime."

Senator Dole, another sponsor, also revealed his image of sex offenders in justifying Rules 413-414. He explained, "I think if somebody is a repeat offender, if you brought in eight or nine women, for example, or eight or nine children, and he had one offense after

69. See Tamara Rice Lave, Inevitable Recidivism: The Origin and Centrality of an Urban Legend, 34 INT. J. OF LAW \& PSYCHIATRY 186 (2011); Tamara Rice Lave, The Iconic Child Molester: What We Believe and Why We Believe It (unpublished manuscript) (on file with the author).

70. See Bob Egelko, Death Sentence Upheld for Polly Klaas' Killer, S.F. CHRON. (June 2, 2009), http://www.sfgate.com/crime/article/Death-sentence-upheld-for-Polly-Klaas-killer-3296333.php;

Defendant in Klaas Slaying Wears High-Voltage Belt in Courtroom, L.A. TIMES (Feb. 8, 1996), http://articles.latimes.com/1996-02-08/news/mn-33758_1_polly-klaas; Davis Faces Death Penalty for Kidnapping and Killing 12-year-old Polly Klaas, CHICAGO TRIB. (June 25, 1996), http://articles.chicagotribune.com/1996-06-25/features/9606250201_1_polly-klaas-richard-allen-davisdeath-penalty.

71. See 'Megan's Law' Killer Escapes Death Under N.J. Execution Ban, CNN (Dec. 17, 2007), http://articles.cnn.com/2007-12-17/politics/death.penalty_1_death-penalty-killer-escapes-death-capitalpunishment?_s=PM:POLITICS; Robert Hanley, Study Says Megan Slaying Fits Pattern for Such Cases, N.Y. TIMES (June 23, 1997), http://www.nytimes.com/1997/06/23/nyregion/study-says-megan-slayingfits-pattern-for-such-cases.htmi?ref-jessektimmendequas; William Glaberson, Doubt is Cast on Claims of Killer's Tortured Life, N.Y. TIMES (June 18, 1997), http://www.nytimes.com/1997/06/18/nyregion/do ubt-is-cast-on-claims-of-killer-s-tortured-life.html?ref-jessektimmendequas.

72. See Jerry Sandusky Trial: All You Need to Know About Allegations, How Case Unfolded, CNN (June 11, 2012), http://news.blogs.cnn.com/2012/06/11/jerry-sandusky-trial-all-you-need-toknow-about-allegations-how-case-unraveled/.

73. 137 Cong. Rec. 26546 (daily ed. Oct. 16, 1991).

74. Id. This statistic can be found on National Alert Registry site at Statistics on Child Molestation, NAT'L ALERT REGISTRY, http://www.registeredoffenderslist.org/blog/sex-offenders/childmolestation-statistics/ (last visited Feb. 9, 2013). 
another, it would be probative." ${ }^{, 75}$ Interestingly, the Senator picked a high number of victims, thus positing a terrifying rate of recidivism. Dole added that "[i]f it had not happened for 10 years, it probably would not have any value." 76

Paul McNulty, former director of policy at the Department of Justice, testified at a congressional hearing on the rules, arguing that the criminal justice system responds inadequately to the scourge of sex crimes. "Given what we know about the recidivist nature of sex offenders, you might think that the criminal justice system does all that it can to keep them in prison. Unfortunately, nothing could be further from the truth." 77

A similar focus on recidivism is apparent in states that adopted versions of Rules 413-414. The Kansas Supreme Court, in calling for a change to Kansas' evidence law (which was later adopted to resemble Rules 413-414) observed:

[T] he modern psychology of pedophilia tells us that propensity evidence may actually possess probative value for juries faced with deciding the guilt or innocence of a person accused of sexually abusing a child. In short, sexual attraction to children and a propensity to act upon it are defining symptoms of this recognized mental illness. ${ }^{78}$

The Kansas Supreme Court further noted that "a diagnosis of pedophilia can be among the justifications for indefinite restriction of an offender's liberty to ensure the provision of treatment to him or her and the protection of others who could become victims." ${ }^{, 79}$ The Court found it "at least ironic that propensity evidence can be part of the support for an indefinite civil commitment, but cannot be part of the support for an initial criminal conviction in a child sex crime prosecution."

The legislative record of the California statute admitting "other acts" character evidence in sex offense cases indicates that proponents also justified the statute by looking at recidivism rates and focusing on the

75. 139 CONG. REC. 27549 (daily ed. Nov. 4, 1993).

76. $1 d$.

77. On a related issue of sex-offender registries, Minnesota Senator Durenberger advocated for legislation that:

[W]ill help communities break the vicious cycle of child sexual victimization, by requiring people who are convicted of sex offenses against children—and these offenders are a group especially prone to recidivism-to register with law enforcement agencies every time they change address, for a period of ten years after their release.

139 CONG. REC. 30580 (daily ed. Nov. 19, 1993) (emphasis added).

78. State v. Prine, 200 P.3d 1, 15-16 (Kan. 2009) (citing the AM. PSYCHIATRIC Ass'N, Diagnostic AND Statistical MANUAl OF MENTAL Disorders 527-28 (4th ed. 1994)).

79. Id. at 16 (citing Kansas' Sexually Violent Predator Act that provides for civil confinement for those who cannot control their dangerousness).

80. Id. 
special deviance of those who commit sex crimes. It cited comments in the Congressional Record regarding the passage of Federal Rules of Evidence and an article written by David Karp, the author of Rules 413$414{ }^{81}$ As the legislative history from the California Senate explained, "The propensity to commit sexual offenses is not a common attribute among the general public. Therefore, evidence that a particular defendant has such a propensity is especially probative and should be considered by the trier of fact when determining the credibility of a victim's testimony." $\$ 82$

Finally, those who call for extension of Rules $413-415$ to the states base their arguments on their perception that the recidivism rate for sex crime perpetrators is unusually high. ${ }^{83}$

\section{What Can PSychology and Criminology Tell Us about PERPETRATOR Profiles AND ReCidivisM?}

As indicated in the previous Part, an essential justification for the propensity rules for sexual misconduct rests on the notion that rape and child molestation are highly unusual crimes perpetrated by a very small disturbed segment of the population with a compulsion to commit such terrible acts repeatedly. We must question the accuracy of these presumptions justifying Rules 413-414 and their state analogs: What are the profiles of rapists and child molesters? What are their recidivism rates?

In trying to answer these questions, one is immediately struck by the divergent ways evidence rulemakers on the one hand, and psychologists and criminologists on the other, approach them. From a legal perspective, law generally applies the same propensity rules for adult rape and child molestation (although a few jurisdictions have a propensity rule just for those who molest children). The law does not, however, differentiate among sub-types of rapists or child molesters.

By contrast, the psychologists and criminologists engage in a much more nuanced approach. Even when they aggregate the data into large groups, researchers in recent years have been careful to distinguish rapists from child molesters and to look at the different risks that offenders pose based on their age and the nature of their crimes.

81. See California Legislature, The Assembly Journal 3277 (1995-96 Regular Session).

82. Sen. Comm. on Criminal Procedure, Floor Analyses of A.B. No. 822, July 18, 1995 , at 8.

83. See, e.g., Lombardi, supra note 33 (listing recidivism rates of rapists and child molesters at around forty-five percent). But see G. Adam Cossey, Note, A Dangerous Leap: The Admission of Prior Offenses in Sexual-Assault and Child-Molestation Cases in Arkansas, 61 ARK. L. REV. 107, 122 (2008) (arguing against the adoption of such rules for Arkansas and noting that "[s]cience, however, has been unable to clearly demonstrate a higher rate of recidivism for sex offenders than for other criminals"). 
The compulsive, repetitive sex offender-one who serially and compulsively preys on women and children and who is the inspiration for the sexual propensity rules-does indeed exist. ${ }^{84}$ But many other types of sex offenders do not fit this image. The critical question for evidentiary purposes is whether the unable-to-control-himself sex offender is sufficiently prevalent to justify a special exception to the rule against propensity evidence.

\section{A. Psychological Profile of Sex-Crime Perpetrators}

Community surveys indicate that $5 \%$ to $20 \%$ of men admit to at least one instance of criminal sexual aggression, whereas 1 to $2 \%$ of the adult male population will eventually be convicted of a sex crime. ${ }^{85}$ In truth, many men rape, and even more say they would do so if they were sure they could get away with it. ${ }^{86}$

Despite the stock image that is often presented in the press, "sex offenders are a heterogeneous group." 87 No particular psychological profile distinguishes sex offenders from other types of criminals. ${ }^{88}$ They can be any race, age, or sexual orientation; they can be repeat offenders or one-time perpetrators. ${ }^{89}$ Many commit other types of crimes, but some exhibit only sex-specific criminal behavior. Yet, sex offenders do share some notable similarities. Most offenders are men; ${ }^{90}$ most victims are women or girls, and the molester is usually a relative of the victim. ${ }^{91}$

84. See Gene G. Abel et al., Self-Reported Sex Crimes of Nonincarcerated Paraphiliacs, 2 J. INTERPERSONAL VIOLENCE 3 (1987).

85. R. Karl Hanson \& Kelly E. Morton-Bourgon, The Characteristics of Persistent Sexual Offenders: A Meta-Analysis of Recidivism Studies, 73 J. Consulting \& CliniCaL Psych. 1154, 1154 (2005).

86. See David Lisak \& Paul M. Miller, Repeat Rape and Multiple Offending Among Undetected Rapists, 17 VIOLENCE \& VICTIMS 73, 73 (2002) (finding 6.4\% of questioned college males (120 out of 1882) self-reported acts qualified as rape or attempted rape; of this group, $63.3 \%$ reported committing repeat rapes, averaging about six rapes per perpetrator). In one experiment, thirty percent of the men polled indicated that if they would not be caught, there would be some likelihood of their raping (rating themselves two or above on a five-point scale). Check \& Malamuth, supra note 68, at 346-47. According to Torrey, one study found that over half the college age male population surveyed would rape if they were assured that they would not be caught or punished. Torrey, supra note 48, at 1023 . See also Nancy Chi Cantalupo, Burying Our Heads in the Sand: Lack of Knowledge, Knowledge Avoidance, and the Persistent Problem of Campus Peer Sexual Violence, 43 LOY. U. CHI. L J. 205, 212 (2011) (citing studies finding that " $35 \%$ of college men indicated some likelihood that they would rape if they could be assured of getting away with it" and a " 1987 study indicat[ing] that $50 \%$ would "force a woman into having sex" if they would not get caught").

87. Berliner, supra note 53, at 1207.

88. Id. at $1207-08$.

89. Id.

90. John B. Murray, Psychological Profile of Pedophiles and Child Molesters, 134 J. PsYCH. $211(2000)$

91. Id. 
In addition, perpetrators against children often claim that they were victims of child abuse themselves. ${ }^{92}$

The American Psychiatric Association (APA) views child molesters very differently from the way it views rapists. The APA has classified pedophilia as a psychiatric disorder since 1968 when it first included it in the Diagnostic and Statistical Manual of Mental Disorders (DSM) ${ }^{93}$ Although the DSM makes it clear that not everyone with pedophilia will molest a child, ${ }^{94}$ its inclusion in the DSM reflects a consensus among psychiatrists of the seriousness of the disorder. ${ }^{95}$ At the same time, not everyone who molests a child is a pedophile. Some adult men who have sex with children do so because the kids are accessible and they can get away with it, not because they have a recurrent, intense sexual attraction to prepubescent children.

By contrast, the APA has never classified rape as a psychiatric disorder. Recently, the authors of the revised DSM-V again rejected including "coercive paraphilia" as a primary diagnosis. ${ }^{96}$ Thus, although rapists may suffer from some form of psychiatric disorder, being a rapist itself is not a mental disorder. Furthermore, most rapists are not sexual sadists as defined by the DSM. ${ }^{97}$ As Allen Frances, MD, Chair of the DSM-IV Task Force, explained:

92. Id.

93. The diagnostic criteria for pedophilia are defined in DSM-IV-TR as follows:

(A) Over a period of at least 6 months, recurrent, intense sexually arousing fantasies, sexual urges, or behaviors involving sexual activity with a prepubescent child or children (generally age 13 years or younger); (B) The person has acted on these sexual urges, or the sexual urges or fantasies cause marked distress or interpersonal difficulty; (C) The person is at least age 16 years and at least 5 years older than the child or children in Criterion A.

Pedophelia, DSM, § 302.2, http://dsm.psychiatryonline.org/content.aspx?bookid=22\&sectionnid=1891 601 (last visited Feb. 9, 2013); see also See What is Pedophilia?, WEB MD, http://www.webmd.com/me ntal-health/features/explaining-pedophilia (last visited Feb. 9, 2013).

94. See Pedophelia, DSM, supra note 93, §302.2(B).

95. See DSM: Frequently Asked Questions, AM. PSYCHIATRY AsS'N, http://www.psychiatry.org/ practicee/dsm/dsm-frequently-asked-questions (last visited Feb. 9, 2013).

96. Allen Frances, DSM 5 Rejects Coercive Paraphilia: Confirming Yet Again that Rape is not a Mental Disorder, PSYCHOL. TODAY (May 26, 2011), http://www.psychologytoday.com/blog/dsm5-indistress/201105/dsm-5-rejects-coercive-paraphilia.

97. The DSM V proposes the following definition of sexual sadism:

A. Over a period of at least 6 months, recurrent and intense sexual arousal from the physical or psychological suffering of another person, as manifested by fantasies, urges, or behaviors. B. The individual has acted on these sexual urges with a nonconsenting individual, or the sexual urges or fantasies cause marked distress or impairment in social, occupational or other important areas of functioning.

Sexual Sadism Disorder, DSM-5 (Apr. 28, 2012), http://www.dsm5.org/ProposedRevisions/Pages/propo sedrevision.aspx?rid=188. This is almost identical to previous definitions. See Richard B. Krueger, The DSM Diagnostic Criteria for Sexual Sadism, ARCH. SEX. BEHAV. (Dec. 2009), http://www.dsm5.org/Documents/Sex\%20and\%20GID\%20Lit\%20Reviews/Paraphilias/KRUEGERSA DISMDSM.pdf. 
For most rapists, violence is no more than a tool to force the nonconsenting person to give in. In contrast, the stereotyped and ritualistic violence in sadistic rape fulfills deep-seated fantasies that are the main event of the sex act. 98

That rapists are not by definition mentally ill is consistent with the feminist insight that rape, particularly acquaintance rape, is widespread. ${ }^{99}$ Rapists are not marked by any obvious character traits, appearance, class, or race, but merely reflect our society's generalized tolerance of violence against women. ${ }^{100}$ Many otherwise normalseeming, socially appropriate men force women to have sex. Others, particularly in the date rape situation, may prefer consensual sex but may willfully misinterpret or be uninterested in the victim's desires. ${ }^{101}$

\section{B. Sex Crime Recidivism Rates}

Psychologists and criminologists study recidivism rates because they wish to prevent future crimes and assess how various treatments are working. ${ }^{102}$ Recidivism rates interest jurists and evidence scholars for an entirely different reason: Are sexual predators so recidivistic in their behavior that once a perpetrator has committed a sex crime, strong evidence exists that he has committed another? Unlike predictions of dangerousness or assessments of treatment plans that look to past behavior to predict future behavior, this use of recidivism employs a propensity argument to contend circumstantially that other past behavior

98. Allen J. Frances, Most Rapists Are Not Sadists: How to Tell the Difference and Why It So Important, PSYCHOL. TODAY (Apr. 20, 2011), http://www.psychologytoday.com/blog/dsm5-indistress/201104/most-rapists-are-not-sadists.

99. See Orenstein, supra note 39; Baker, supra note 67.

100. By focusing on women as victims, we do not mean to imply that men are not victims of rape. See, e.g., Bennett Capers, Real Rape Too, 99 CAL. L. REV. 1259 (2011) (calling for reform on attitudes towards male rape); James E. Robertson, The "Turning-Out" of Boys in a Man's Prison: Why and How We Need to Amend the Prison Rape Elimination Act, 44 IND. L. REV. 819 (2011) (discussing rape of young male inmates in adult prisons); CDC, Youth Risk Surveillance Behavior, 61 SURVEILLANCE SUMMARIES 1, 66 (2012) (4.5\% of high school boys questioned reported having been physically forced to have sex at some point in their lives); Leslie Linthicum, The Nightmare of Male Rape, ABQ J (Jul. 8, 2012), http://www.abqjournal.com/main/2012/07/08/upfront/the-nightmare-of-male-rape.html.

101. See Andrew E. Taslitz, Willfully Blinded: On Date Rape and Self-Deception, 28 HARV. J.L. \& GENDER 381, 382, 388-98 (2005) (explaining how date rape often happens due to male "selfdeception," which occurs when the alleged rapist consciously, but incorrectly, believes he has the woman's consent when, at some less-than-fully conscious level, he knows otherwise); R. Karl Hanson \& Heather Scott, Assessing Perspective-Taking Among Sexual Offenders, Nonsexual Criminals, and Nonoffenders, 7 SEXUAL ABUSE 259, 259-77 (1995); Neil M. Malamuth \& Lisa M. Brown, Sexually Aggressive Men's Perceptions of Women's Communications: Testing Three Explanations, $67 \mathrm{~J}$. PERSONALITY \& SOC. PSYCH. 699, 699-712 (1994).

102. See, e.g., Hanson \& Morton-Bourgon, supra note 85 , at 1154 . The prior bad act need not be convicted conduct. The judge need only find that the jury could reasonably believe the prior act occurred to admit it under Rules 413-414. 
occurred. Thus, even if all sex offenders were highly recidivistic - a proposition that we will show is not supported by existing studiesthere is nevertheless a legitimate question concerning how jurists and evidence scholars should use the data. Mere statistical correlations of tendencies of a group of past offenders do not address the actions of a particular offender. Being statistically predisposed to reoffend does not mean the person actually did so. ${ }^{103}$ People are more interesting and complicated than that. ${ }^{104}$

In discussing recidivism rates, it is essential to distinguish general recidivism (commission of any subsequent crime) from recidivism specifically for a sex crime. The justification for Rules $413-414$ is not that the accused will commit some random other future crime, but that a past sex crime is highly predictive of more of the same. Study after study, however, has cast doubt on this core assumption.

\section{Department of Justice Study (2003)}

In 2003, the Department of Justice (DOJ) published a report studying the recidivism of sex offenders who had been released in $1994 .{ }^{105}$ The DOJ study followed 9,691 sex offenders-the entire population of violent sex offenders released from prison in fifteen states. ${ }^{106}$ "Violent" means that the offender either used or threatened to use force or, although the offender did not use force, he did not have the victim's "factual" or "legal consent." Lack of factual consent means that for physical reasons, the victim did consent, such as when the victim was unconscious. Lack of legal consent means that the victim willingly participated in the sexual act but was deemed too young or of

103. Thanks to Miguel Mendez for reemphasizing this point to us.

104. A faith, particularly in America, in the human ability to change is evidenced by the plethora of self-help books and twelve step programs. See Esra Coker Körpez, Urban Values and American Self Help: Reading the "City" As an Agent of Self-Transformation, TRANS: INTERNET-ZEITSCHRIFT FÜR KULTURWISSENSCHAFTEN (Jan. 2012), http://www.inst.at/trans/18Nr/II-2/koerpez18.htm ("The United States with its 2.48 billion dollar a year self-improvement industry that makes up 6 percent of the entire book market is one of the leaders in the world in selling, marketing and spreading a privatized concept of the self whose potential of growth is unlimited and inexorable. In fact, it would not be misleading to say that self-help is in the cultural DNA of the United States where individuals continuously struggle to realize themselves by mapping out their life projects all with the sense that it is their life choices that play a prominent role in their making as well as their unmaking."); ROBERT J. LIFTON, THE PROTEAN SELF: HUMAN RESILIENCE IN AN AGE OF FRAGMENTATION (1993) (describing and lauding the modem ability to reinvent oneself amid the challenge of a rapidly changing world); Robin Room, "Healing Ourselves and our Planet": The Emergence of a Generalized Twelve-Step Consciousness, 19 CONTEMP. DRUG. PROBS. 717 (1992) (describing some of the features of "12-step consciousness").

105. Patrick A. Langan, Erica L. Schmitt \& Matthew R. DuRose, Recidivism of Sex OFFENDERS RELEASED FROM PRISON IN 1994, at 1 (2003) [hereinafter DOJ].

106. Arizona, California, Delaware, Florida, Illinois, Maryland, Michigan, Minnesota, New Jersey, New York, North Carolina, Ohio, Oregon, Texas, and Virginia. Id. at 1. 
insufficient mental competence to do so. ${ }^{107}$

The authors of the study then looked at the prison and other records to subdivide the offenders by nature of crime. ${ }^{108}$ They were subdivided into four categories: 3,115 rapists; 6,576 sexual assaulters; 4,295 child molesters, and 443 statutory rapists. ${ }^{109}$ Researchers continued to track released offenders during the entire three-year period. ${ }^{110}$ If, for instance, a person was rearrested for burglary and then later for rape, both of those arrests would have been recorded. ${ }^{111}$

The DOJ found that $5.3 \%$ (517) of convicted sex offenders were rearrested for a new sex crime within three years after release from prison. ${ }^{112}$ The DOJ then looked at the recidivism rates of specific types of sex offenders. They found that $5.0 \%$ (155) of convicted rapists, ${ }^{113} 5.5 \%(362)$ of sexual assaulters, $5.0 \%(22)$ of statutory rapists, and $5.1 \%(221)$ of child molesters ${ }^{114}$ were rearrested for a new sex crime within 3 years after release. All of those rearrested for a new sex crime were men. ${ }^{15}$

As compared with almost all other types of offenders, released sex offenders were the least likely to be rearrested for the same crime within three years of release from prison. The Bureau of Justice Statisticians Langan and Levin found that $2.5 \%$ of rapists were rearrested for rape, ${ }^{116}$ and the DOJ found that $3.3 \%$ of child molesters were arrested for another sex crime against a child. ${ }^{117}$ In contrast, during that same three year period, Langan and Levin found that $13.4 \%$ of robbers were rearrested for robbery; $22 \%$ of assailants were rearrested for assault; $23.4 \%$ of burglars were rearrested for burglary; $33.9 \%$ of thieves were rearrested for larceny or theft; $11.5 \%$ of car thieves were rearrested for car theft; and $41.2 \%$ of drug offenders were rearrested for a drug crime. Among released offenders only those convicted of homicide had a specialized recidivism rate lower than rapists and child molesters. ${ }^{118}$

107. DOJ, supra note 105 , at 3 .

108. Id. at 37.

109. Id. at 1 . It was possible for these categories to overlap; for instance, a person could be categorized as a rapist and a child molester.

110. Id.

111. Id. at 34 .

112. Id.

113. Id. at 24.

114. Id.

115. Id.

116. Patrick A. Langan \& David J. Levin, Recidivism of Prisoners Released IN 1994 (2002).

117. DOJ, supra note 105 , at 1 .

118. Just $1.2 \%$ of homicide perpetrators were rearrested for homicide within three years after release from prison. LANGAN \& LEVIN, supra note 116, at 9. 
In sum, the DOJ study indicates that few sex offenders are rearrested for committing a new sex crime, and sex offenders are less likely than non-sex offenders to be rearrested for any crime at all. Forty-three percent of sex offenders released in 1994 were arrested for a new crime within three years (but that figure, of course. includes non-sex crimes). ${ }^{119}$ In contrast, $67.5 \%$ of non-sex offenders released in 1994 were arrested for any new crime within three years. ${ }^{120}$

Although convicted sex offenders have a low recidivism rate, they were significantly more likely to be arrested for a new sex crime than released offenders who had not been convicted of a sex crime. ${ }^{121}$ Compared to $5.3 \%$ of convicted sex offenders, only $1.3 \%$ of persons convicted for non-sex-related offenses were subsequently arrested for a sex crime within three years after release. ${ }^{122}$ Less than half of $1 \%$ of those people previously convicted of a non-sex offense were rearrested for a new sex crime against a child. ${ }^{123}$ Put another way, Langan and Levin calculated that a rapist's odds of being rearrested for a new rape are 3.2 times greater than a non-rapist's odds of such an arrest. ${ }^{124}$ This comparison, however, should not obfuscate the larger point that statistically, sex-crime offenders have much lower recidivism rates for sex crimes than robbers, drug addicts, and assailants have for repeating their convicted offenses.

\section{Other Recidivism Studies}

Other studies have reached similar conclusions. In 2009, Hanson and Morton-Bourgnon conducted a meta-analysis of twenty-one sex offender studies from the United States, Canada, the United Kingdom, and other countries and found an overall sexual recidivism rate of

119. DOJ, supra note 105 , at 13.

120. LANGAN \& LEVN, supra note 116 , at 1.

121. This fact has led to some confusion in reading the DOJ data. See, e.g, Kahn, supra note 33, at 653-54 ("Another distinguishing factor of sex crimes is the high recidivism rates among sex offenders. According to a 2003 Department of Justice report, sex offenders were rearrested for new sex crimes within three years of release at a rate four times greater than other released convicts. Department of Justice data concluded that ' $[\mathrm{r}]$ eleased rapists were 10.5 times as likely as non-rapists to be arrested for rape' and that people convicted of sexual assault were '7.5 times as likely as those convicted of other crimes to be arrested for a new sexual assault."'); Sherry L. Scott, Comment, Fairness to the Victim: Federal Rules of Evidence 413 and 414 Admit Propensity Evidence in Sexual Offender Trials, 35 Hous. L. REv. 1729, 1740 (1999) (citing a Psychology Today article for the conclusion that "sexual offenses involve highly repetitive behavior" and asserting that some child molesters "are habitual offenders, basically incurable, and should be incarcerated for life" based on Kansas v. Hendricks, which permitted incarceration of habitual sexual offenders after they completed their criminal term).

122. DOJ, supra note 105 , at 24.

123. Id. at 30 .

124. LANGAN \& LEVIN, supra note 116 , at 10. 
$11.5 \%{ }^{125}$ In 1998, Hanson and Bussière conducted a similar metaanalysis of 61 studies from six different countries including the United States. ${ }^{126}$ They found that over an average follow-up time of four to five years, the sex offense recidivism rate was $13.4 \% .{ }^{127}$ In 2007 , using arrest data from 1990-1997 collected by the Illinois State Police, ${ }^{128}$ Sample and Bray found that fewer than $4 \%$ of convicted child molesters were rearrested for any sex offense within one, three, or five years after their release from custody. ${ }^{129}$ They also found that approximately $7 \%$ of convicted rapists were rearrested for any sex offense within five years after release. ${ }^{130}$ In 1997, the DOJ released a study authored by Allen J. Beck and Bernard E. Shipley at the Bureau of Justice Statistics that analyzed the recidivism rate of rapists released from prison in $1983 .{ }^{131}$ Beck and Shepley found that $7.7 \%$ of rapists were rearrested for rape within three years of release. ${ }^{132}$

Other studies, however, have found significantly higher recidivism rates. For instance, Hanson, Scott, and Steffy studied the long-term recidivism of 191 child molesters released from a maximum-security, provincial correctional institution in Ontario, Canada. ${ }^{133}$ Their recidivism rate, as defined by conviction for a new sex crime over a 15 to 30 year period, was $35.1 \% .{ }^{134}$ As another example, Rice, Harris, and Quinsey followed 54 rapists (defined as anyone who had sexually

125. R. Karl Hanson \& Kelley E. Morton-Bourgon, The Accuracy of Recidivism Risk Assessments for Sexual Offenders: A Meta-Analysis of 118 Prediction Studies, 21 PSYCHOL. ASSESSMENT 1, 3-4, 6 (2009) (evaluating accuracy of prediction models). The recidivism rate is higher if other types of crimes are included. For prior sex-crime perpetrators, the sexual or violent recidivism rate is $19.5 \%$; it is $33.2 \%$ if all types of crimes are considered. Id.

126. R. Karl Hanson \& Monique T. Bussière, Predicting Relapse: A Meta-Analysis of Sexual Offender Recidivism Studies, 66 J. CONSULTING \& ClINICAL PSYCH. 348, 350 (1998).

127. Id. at 357 .

128. Lisa L. Sample \& Timothy M. Bray, Are Sex Offenders Different? An Examination of Rearrest Patterns, 17 CRIM. JUST. POL'Y REV. 83, 88 (2006).

129. Id. at 95 .

130. Id.

131. Allen J. BeCK \& Bernard E. Shipley, Recidivism of Prisoners Released IN 1983 (1989).

132. Id. at 6 .

133. R. Karl Hanson, Heather Scott \& Richand A. Steffy, A Comparison of Child Molesters and Non-Sexual Criminals: Risk Predictors and Long-Term Recidivism, 32 J. RESEARCH IN CRIME \& DELNQUENCY 325, 327 (1995).

134. Id. at 332 . In assessing the relevance of this study, it is critical to note that this study has a much smaller sample size than the DOJ study (191 vs. 9,691), occurred in a different place (Canada vs. the U.S.), and offenders concerned were released decades before (1958-1974 vs. 1994-1997). For an in-depth discussion of the differences between these two studies, see Tamara Rice Lave, Controlling Sexually Violent Predators: Continued Incarceration At What Cost, 14 NEW CRIMINAL L. R. 213, 24547. 
assaulted or attempted to sexually assault a female age 14 or older) ${ }^{135}$ released from a maximum-security psychiatric hospital in Canada. ${ }^{136}$ Their average age was 30 with a standard deviation of approximately $10{ }^{137}$ The average follow-up period was 46 months, and recidivism was defined as conviction for a new sex crime. The recidivism rate was $28 \% .{ }^{138}$ Even if these higher numbers are correct, they are still significantly below the recidivism rates for other types of offenders. For instance, Langan and Levin found that during a three-year period, 33.9\% of thieves were rearrested for larceny or theft, and $41.2 \%$ of drug offenders were re-arrested for a drug crime. ${ }^{139}$

\section{Sexual Recidivism Rates over Time}

Studies uniformly indicate that recidivism rates drop each year after an offender's release.

For all crimes (and almost all behaviours) the likelihood that the behavior will reappear decreases the longer the person has abstained from that behaviour. The recidivism rate within the first two years after release from prison is much higher than the recidivism rate between years 10 and 12 after release from prison. ${ }^{140}$

Harris and Hanson found that the rate of recidivism in the populations they studied decreased by half every five years. ${ }^{141}$ An earlier study by the same authors found that the risk of individual recidivism decreases over time-from $14 \%$ at the five-year mark, to $20 \%$ at the ten-year mark, and $27 \%$ at the twenty-year mark. ${ }^{142}$ Thus, the longer someone remains in the community without reoffending, the less likely it is that

135. Mamie E. Rice, Grant T. Harris, \& Vemon L. Quinsey, A Follow-Up of Rapists Assessed in a Maximum-Security Psychiatric Facility, 5 J. INTERPERSONAL VIOLENCE 435, 437 (1990). This study utilized a broader definition of rape than would be employed under U.S. criminal law.

136. Id.

137. Id. at 439. The average age at the time of release for those who reoffended and those who did not was 29.9, but the standard deviation for those who did not recidivate was 10.2 and for those who did was 29.9. Id.

138. Id. at 442.

139. LANGAN \& LEVIN, supra note 116, at 9. Langan and Levin also found that $13.4 \%$ of robbers were rearrested for robbery; $22 \%$ of assailants were rearrested for assault; $23.4 \%$ of burglars were rearrested for burglary; and $11.5 \%$ of car thieves were rearrested for car theft. Id.

140. ANDREW J.R. HARRIS \& R. KARL HANSON, SEX OFFENDER RECIDIVISM: A SIMPLE QUESTION 3 (Public Safety and Emergency Preparedness Canada 2004).

141. Id. at 11 .

142. R. Karl Hanson, Kelley E. Morton \& Andrew J.R. Harris, Sexual Offender Recidivism Risk: What We Know and What We Need to Know, 989 ANNALS N.Y. ACAD. SCl. 154, 155 (2003) [hereinafter Sexual Offender Recidivism Risk] ("The five-year recidivism rate was $14 \%$. . the 10-year recidivism rate was $20 \%$."). 
he will do so. ${ }^{143}$

A similar, though steeper, downward trend is evident in the DOJ data, which indicate that sex offenders released in the United States were most likely to be arrested in the first year, and the rate declined every subsequent year. ${ }^{144}$ Of the 513 sex offenders who were rearrested: $40 \%$ (205) were rearrested in the first year, 34\% (174) in the second, and $26 \%(133)$ in the third. Of the 156 rapists who recidivated (i.e., were arrested for a new sex crime within three years of release): $40 \%(62)$ recidivated within the first year, $34 \%$ (53) in the second, and $26 \%$ (41) in the third. With child molesters, the rates dropped even more quickly. Of the 219 child molesters who were arrested for a new sex crime against a child within three years of release: $43 \%(94)$ were arrested in the first year, $33 \%$ (72) in the second, and $24 \%$ (53) in the third.

If this same downward trend were to continue, then the recidivism rate of sex offenders would reach $11 \%$ between ten and fifteen years after release from prison. (The number of additional rearrests would drop to a negligible level at that time.) Similarly, the recidivism rate of child molesters would reach $9 \%$ between ten and fifteen years after release from prison. Again, the number of additional re-arrests would drop to a negligible level at this time. ${ }^{145}$

\section{The Effect of Age on Recidivism}

Most sex offenders do not recidivate, and like other types of offenders, their risk of doing so decreases as they age. In 2002, R. Karl Hanson used data from ten follow-up studies of adult male sex offenders (combined sample of 4,673) to study the relationship between age and sexual recidivism. He found that "[i]n the total sample, the recidivism rate declined steadily with age." Furthermore, "[t]he association was linear." 146

Interestingly, Hanson found significant differences among offender groups. Rapists were younger than other types of sex offenders. ${ }^{147}$ Almost half were younger than 30 , and their risk of recidivating dropped steadily with age, with no one reoffending over age $60 .{ }^{148}$ The risk of recidivating for extra-familial child molesters rose from ages 18 to 25

143. Id. at 155 .

144. Hanson \& Morton-Bourgon, supra note 125 , at 16.

145. For a detailed discussion of these computations, see Tamara Rice Lave, Controlling the Sexually Violent Predator: Continued Incarceration at What Cost?, 14 NEW CRIM. L. REV. 213, app. C (2011).

146. R. Karl Hanson, Recidivism and Age: Follow-Up Data from 4,673 Sexual Offenders, $17 \mathrm{~J}$. INTERPERSONAL VIOLENCE 1046, 1053 (2002).

147. Id. at 1056.

148. Id. at 1054 
and then began dropping at a slow but continuous rate until the age of 50 , when it declined dramatically. ${ }^{149}$ Hanson found that, although it continued to drop, the highest recidivism rate occurred in extra-familial child molesters between the ages of 25 and $35 .{ }^{150}$ Hanson found that incest offenders presented significantly lower recidivism rates overall and that they declined steadily with the offender's age. The highest recidivism rate for incest offenders occurred between the ages of 18 and $24 .^{151}$

Other researchers have reported similar results, ${ }^{152}$ even when analyzing the age effect on a sample of offenders with a higher recidivism rate than the general prison population. ${ }^{153}$

\section{E. The Effectiveness of Treatment}

Compounding concern about recidivism rates is a sense of helplessness born from the belief that sexual predators are impervious to treatment. Although such a belief made sense in the past, treatment has

149. Id.

150. Id.

151. Id.

152. See Howard E. Barbaree et al., Aging Versus Stable Enduring Traits as Explanatory Constructs in Sex Offender Recidivism: Partitioning Actuarial Prediction into Conceptually Meaningful Components, 36 CRIM. JUST. \& BEHAV. 443, 443 (2009) ("A large body of evidence has recently accumulated indicating that recidivism in sex offenders decreases with the age of the offender at the time of his release ...."); Patrick Lussier \& Jay Healey, Rediscovering Quetelet, Again: The "Aging" Offender and the Prediction of Reoffending in a Sample of Adult Sex Offenders, 26 JUST. Q. 827, 851 (2009) (finding that the risk of recidivism decreases with age); Patrick Lussier et al., Criminal Trajectories of Adult Sex Offenders and the Age Effect: Examining the Dynamic Aspect of Offending in Adulthood, 20 INT'L CRIM. JUST. REV. 147, 164 (2010) (offering "several explanations as to why older sex offenders represent a lower risk of recidivism"); Richard Wollert et al., Recent Research $(n=9,305)$ Underscores the Importance of Using Age-Stratified Actuarial Tables in Sex Offender Risk Assessments, 22 Sexual AbuSE: J. ReS. \& TREATMENT 471, 484 (2010) (concluding that "evaluators should report recidivism estimates from age-stratified or equivalent tables when they are assessing sexual recidivism risk, particularly when evaluating the aging sex offender").

153. In 2007, Prentky and Lee looked at the age effect on a cohort of 136 rapists and 115 child molesters who had been civilly committed to a Massachusetts prison and were then followed for twentyfive years. They found that with rapists, recidivism dropped linearly as a function of age. With child molesters, however, they found that recidivism increased from age 20 to age 40 and then declined slightly at age 50 and significantly at age 60 . Robert Alan Prentky \& Austin F.S. Lee, Effect of Age-atRelease on Long Term Sexual Re-Offense Rates in Civilly Committed Sexual Offenders, 19 SEXUAL ABUSE: J. RES. \& TREATMENT, 43, 53 (2007). As Prentky and Lee point out, their sample is statistically small and included offenders with a higher base rate of recidivism than those drawn from the general prison population.

Although this latter consideration must be regarded as a limitation in terms of generalizability, it may also be seen as strength of the study. Presumably, using a higher risk sample is a more severe test of the age-crime hypothesis, providing confirmatory support for the rapists and 'amplifying' or exaggerating the quadratic blip in Hanson's (2002) data for child molesters.

Id. at 58 . 
improved significantly since the 1970 s. ${ }^{154}$ For instance, a 2001 study by Beech, Erikson, Friendship, and Ditchfield and a 2002 study by Marques, Day, Wiederanders, and Nelson both found that progress in sex offender treatment was significantly correlated with lowered recidivism. Hanson, Gordon, Harris, Marques, Murphy, Quinsey, and Seto (Hanson et al.) conducted a meta-analysis of 43 studies involving more than 9,000 offenders in which they found that current cognitivebehavioral treatments reduced sexual recidivism by $43 \% .{ }^{155}$ A metaanalysis including eighty studies that followed over 22,000 individuals concluded that some treatments do have positive and significant effects on recidivism. The most effective is surgical or chemical castration, in part because willingness to undergo it bespeaks the perpetrator's strong incentive to change his behavior. ${ }^{156}$ Another meta-analysis of 9,000 offenders in forty-three studies found that treatment lowered sexoffender recidivism from 17.3 to $9.9 \%$, a drop of $43 \% .{ }^{15}$

Interestingly, Hanson et al. found that refusal to participate in treatment was not associated with higher recidivism for sex offenses as compared with those who participated in treatment. ${ }^{158}$ Refusal was associated with higher general recidivism (i.e., recidivism for any crime). ${ }^{159}$ Dropping out after treatment began, however, was correlated

154. R. Karl Hanson et al., First Report of the Collaborative Outcome Data Project on the Effectiveness of Psychological Treatment for Sex Offenders, 14 SEXUAL ABUSE 169, 188 (2002).

155. Id. at $186-187$.

156. See Anthony Beech \& Hannah Ford, The Relationship Between Risk, Deviance, Treatment Outcome and Sexual Reconviction in a Sample of Child Sexual Abusers Completing Residential Treatment for their Offending, 12 PSYCH., CRIME \& L. 685 (2006) (finding that none of the high risk/high deviance men who left the residential treatment program having responded to treatment had been reconvicted of a sexual offense during the follow-up period); Friedrich Lösel \& Martin Schmucker, The Effectiveness of Treatment for Sexual Offenders: A Comprehensive Meta-Analysis, $1 \mathrm{~J}$. EXPERIMENTAL CRIMINOLOGY 117, 134-35 (2005) (considering psychological, chemical, and surgical treatments for perpetrators and finding cognitive behavioral and hormonal treatment as the most promising). See also Hanson \& Morton-Bourgon, supra note 85, at 1159 ("On average, sexual offenders who attend treatment are less likely to recidivate than are comparison groups, but it is easy to locate well-controlled studies that find no effect for sexual offender treatment."); Mario J. Scalora \& Calvin Garbin, A Multivariate Analysis of Sex Offender Recidivism, 47 INT'L J. OFFENDER THERAPY \& COMPARATIVE CRIMINOLOGY 309, 314 (2003) (finding that "treated child molesters were significantly less likely to reoffend compared to their untreated counterparts"). But see Janice K. Marques et al., Effects of a Relapse Prevention Program on Sexual Recidivism: Final Results From California's Sex Offender Treatment and Evaluation Project (SOTEP), 17 SEXUAL ABUSE 79 (2005) (finding that inpatient relapse prevention treatment had no significant effect on reoffending over an eight-year follow up period as compared to a control group who received no treatment; however, closer examination found that those who met the program's treatment goals had a lower recidivism rate than those who did not). Id.

157. Hanson et al., supra note 154 , at 187 . It also lowered general recidivism from $51 \%$ to $32 \%$.

158. Id.

159. Id. 
with a higher rate of sexual recidivism. ${ }^{160}$

Not all experts agree on the effectiveness of treatment. Levenson and D'Amora reviewed various studies on the efficacy and found that "although the research is not unequivocal, there is evidence to believe that treatment can be helpful for many sex offenders." actually found that sex offender treatment was non-significantly associated with increased recidivism. ${ }^{162}$

\section{$F$. The Effect of Gender}

In a recent meta-analysis of ten studies, Cortoni, Hanson, and Coache found that women sex offenders had a very low sexual recidivism rate. ${ }^{163}$ They followed 2,416 female sex offenders and found that between $1 \%$ to $3 \%$ recidivated sexually. ${ }^{164}$ They concluded, "These results provide clear evidence that female sexual offenders, once they have been detected and sanctioned by the criminal justice system, tend not to reengage in sexually offending behavior."165 They added that, at this point, "The risk factors for sexual recidivism among females are unknown ...."

\section{G. Additional Factors Related to Recidivism}

"No single risk factor is sufficient to predict whether a particular offender will reoffend or not."167 Hanson and Morton-Bourgon conducted a meta-analysis of eighty-two studies and found that the two strongest predictors of sexual recidivism were sexual deviancy ${ }^{168}$ and antisocial orientation. ${ }^{169}$ They also found that factors such as "sexual preoccupations, lifestyle/impulsivity, pro-offending attitudes, and

160. Id. at $186-87$.

161. Jill S. Levenson \& David A. D'Amora, Social Policies Designed to Prevent Sexual Violence, 18 CRIM. JUST. POL'Y REV. 168, 179 (2007).

162. Grant T. Harris et al., A Multisite Comparison of Actuarial Risk Instruments for Sex Offenders, 15 PSYCHOL. ASSESSMENT 413 (2003).

163. Franca Cortoni et al., The Recidivism Rates of Female Sexual Offenders Are Low: A MetaAnalysis, 22 SEXUAL ABUSE 387 (2010).

164. Id. at 394.

165. Id. at 396 .

166. Id. at 398 .

167. Sexual Offender Recidivism Risk, supra note 142, at 158.

168. Deviant sexual interest means that a person has an enduring attraction to illegal sexual acts (such as sex with a child) or highly unusual sources of arousal (such as fetishism). Hanson \& MortonBourgnon, supra note 85 , at $1154-57$.

169. Antisocial orientation refers to antisocial personality, antisocial traits, and a history of violating rules. $I d$. at 1157 . 
intimacy deficits" also influenced recidivism. ${ }^{170}$ In an earlier study, Hanson and Bussière found the following factors to be slightly predictive of sexual recidivism: the existence of prior sexual offenses, the fact that victim was a male, that the victim was a stranger, that the victim was extra-familial, and that he began offending at an early age. ${ }^{171}$

Interestingly, Hanson and Bussière found that the following were not associated with recidivism: the degree of sexual contact, the extent of force used, and the infliction of injury to the victim. ${ }^{172}$ They also found that low remorse, low victim empathy, and denial were unrelated to sexual recidivism. ${ }^{173}$

\section{H. Recidivism Rates for Sex Abuse of Children}

As discussed above, the DOJ found that $3.3 \%$ of child molesters were rearrested for a new sex crime against a child within three years of release from prison. Recidivism in child molesters is based on a number of factors: "The more deviant the sexual practices of the offender; the younger the abused child; the more sociopathic or antisocial personality traits displayed; the greater the treatment noncompliance; and the greater the number of paraphilic interests reported by the offender, the higher the likelihood of reoffense."174 As opposed to rapists, child molesters reported less socially deviant behavior over their lifetime, and they started criminal activity later in life. ${ }^{175}$

In addition, the recidivism rate varies significantly according to the relationship between the perpetrator and the victim. ${ }^{176}$ Child molesters who abuse children within their own family (such as children, stepchildren, and nieces and nephews) have the lowest recidivism rates. ${ }^{177}$ "Among child molesters, those most likely to sexually

170. Id. at 1159 .

171. Hanson \& Bussière, supra note 126, at 351-52.

172. Id. at 351 .

173. Id. at 357 .

174. Hall \& Hall, supra note 58, at 467.

175. Patrick Lussier, Marc LeBlanc \& Jean Proulx, The Generality of Criminal Behavior: $A$ Confirmatory Factor Analysis of the Criminal Activity of Sex Offenders in Adulthood, 33 J. CRIM. JUST. 177,186 (2005).

176. See Berliner, supra note 53, at 1209 ("Recidivism rates, however, vary dramatically depending on the subpopulation of interest. Some groups of sex offenders, such as men who commit incest, are at quite low risk to reoffend, while others, for example those with multiple prior sex offense convictions, are at relatively high risk to reoffend.").

177. See Sexual Offender Recidivism Risk, supra note 142, at 155-156; David Greenberg et al., Recidivism of Child Molesters: A Study of Victim Relationship with the Perpetrator, 24 CHILD ABUSE \& NEGLECT 1485 (2000) ("A larger portion of men (16.2\%) who sexually offended against children who were acquaintances, were charged with a new sexual offense than men who sexually offended against biological $(4.8 \%)$ or their stepchildren $(5.1 \%) . ")$. 
recidivate are those who offended against unrelated boy victims, followed by those who offended against unrelated girl victims and, finally, incest offenders." 178 A study of sex offenders released from Arizona prisons found that $14 \%$ of extrafamilial child molesters were charged with a new sexual offense within five years, compared to $11 \%$ of incest child molesters. ${ }^{179}$ Another study found that $16.2 \%$ of men who sexually offended against acquaintances recidivated as compared with $5.1 \%$ who had offended against their stepchildren and $4.8 \%$ of those who had offended against their biological children. ${ }^{180}$

\section{Recidivism Rates for Rape}

As discussed above, the DOJ found that $2.5 \%$ of rapists were rearrested for a rape within three years of release from prison. Several studies suggest that rapists are more similar to the general criminal population than are child molesters. The results of one study suggest that "the prediction of recidivism for rapists may not differ substantially from that for general offenders .... [R]apists may be characterized by manifesting a general pattern of antisocial deviance that persists over time-their sexual offenses may merely be one more manifestation of their deviant behavior." 181 Indeed, one meta-analysis found that although rapists and child molesters had similar recidivism rates, "[r]apists ... [were] much more likely than child molesters to recidivate with a nonsexual violent offense." $" 182$ The behavior of rapists was consistent with theories that explain criminal behavior as caused by lack of self-control and inability to resist deviant opportunities and could be explained the same way as the behavior of other types of criminals. ${ }^{183}$

\section{J. An Important Caveat Regarding Underreporting}

The DOJ study cited above reports the number of sex offenders who were rearrested for a new sex crime within three years of release from

178. Sexual Offender Recidivism Risk, supra note 142, at 155-156.

179. Darci L. Bartosh et al., Differences in the Predictive Validity of Actuarial Risk Assessments in Relation to Sex Offender Type, 47 INT'L J. OFFENDER THERAPY \& COMP. CRIMNOLOGY 422, 429 tbl.2 (2003) (both extrafamilial and incest molesters had around a $45 \%$ general recidivism rate for any type of crime).

180. See Greenberg et al., supra note 177.

181. Genevieve Parent, Jean-Pierre Guay \& Raymond A. Knight, An Assessment of Long-Term Risk of Recidivism by Adult Sex Offenders: One Size Doesn't Fit All, 38 CRIM. JuST. \& BEHAV. 188, 204 (2011) (studying recidivism rates of sex offenders-child molesters, rapists, and those who had committed both offenses- to determine accuracy of recidivism prediction models).

182. Sexual Offender Recidivism Risk, supra note 142, at 155 (citations omitted).

183. Id. 
prison; however, these numbers undoubtedly understate the actual recidivism rate in two ways. First, there may be errors in reporting the data. The arresting police agency may not have sent all of the appropriate records to the agency gathering data, or the data may be misreported. ${ }^{184}$ Second, and more significantly, the DOJ has no way of considering crimes that law enforcement did not detect. Many scholars contend that the rate of underreporting in sex cases is high. ${ }^{185}$

Sex crimes may not be reported to law enforcement because, when they involve family members or friends, victims may not want to risk incriminating someone they care about or rely upon. ${ }^{186}$ In addition, a victim may be embarrassed or blame herself for what occurred. ${ }^{187}$ The victim may be distrustful of the police or the court system or fear reprisal or the possible repercussions to her assailant. ${ }^{188}$ Alternatively, the victim may not realize that what happened was a crime. A child victim might have told a parent or guardian who did not take the allegation seriously, especially if the accused is a close family member

184. LANGAN \& LEVIN, supra note 116 , at 58.

185. Mary P. Koss et al., The Scope of Rape: Incidence and Prevalence of Sexual Aggression and Victimization in a National Sample of Higher Education Students, 55 J.CoUNSELING \& CLINICAL PSYCH. 162, 162-70 (1988); John J. Sloan III et al., Assessing the Student Right to Know and Campus Security Act of 1990: An Analysis of the Victim Reporting Practices of College and University Students, 43 CRIME \& DelinquenCY 148, 148-68 (1997); Jody Clay-Warner \& Callie Harbin Burt, Rape Reporting After Reforms: Have Times Really Changed?, 11 VIOLENCE AGAINST WOMEN 150 (2005); Bonnie S. Fisher et al., Reporting Sexual Victimization to the Police and Others: Results from a National-Level Study of College Women, 30 CRIM. JUSTICE \& BEHAV. 6 (2003); Lita Furby et al., Sex Offender Recidivism: A Review, 105 PsYCH. Bull. 3, 9 (1989). For instance, Sloan III et al. conducted a national study of college students in which they found that only $22 \%$ of rapes and $17 \%$ of sexual assaults were reported to local law enforcement, campus police, or security or other authorities. Sloan III et al., supra, at 148-68.

186. See Fisher et al., supra note 185, at 10-12; see also Levenson \& D'Amora, supra note 161, at 178 .

187. See Amy L. Brown \& Maria Testa, Social Influences on Judgments of Rape Victims: The Role of the Negative and Positive Social Reactions of Others, 58 SEX ROLES 490 (2008); Bonnie L. Katz \& Martha R. Burt, Self Blame in Recovery from Rape: Help or Hindrance, in ANN WOLBERT BURGESS ED., RAPE AND SEXUAL ASSAULT II, 345-58 (1998); Louise Ellison \& Vanessa E. Munro, Reacting to Rape: Exploring Mock Jurors' Assessments of Complainant Credibility, 49 BRIT. J. CRIMINOLOGY 202, 210 (2009).

188. Meghan Casey, Refugee Women As Cultural Others: Constructing Social Group and Nexus For FGM, Sex Trafficking, and Domestic Violence Asylum Claims in the United States, 10 SEATTLE J. SOC. JUST. 981, $1035 \mathrm{n} .259$ (2012) ("Reasons for not informing the police include the victims' belief that their victimization was a private or personal matter, fear of retaliation, and feeling that the police would not be able to help them."); BONNIE S. FiSHER ET AL., SEXUAL VICTIMIZATION OF COLLEGE WOMEN 8 (2000), available at http://www.ncjrs.gov/pdffiles 1/nij/182369.pdf (reporting that reasons for college women not reporting rapes included "not wanting family or other people to know about the incident, lack of proof the incident happened, fear of reprisal by the assailant, fear of being treated with hostility by the police, and anticipation that the police would not believe the incident was serious enough and/or would not want to be bothered with the incident"). 
or trusted friend. ${ }^{189}$

In 2006, the Bureau of Justice Statistics (BJS) estimated that $41.4 \%$ of all forcible rapes and sexual assaults were reported to the police. ${ }^{190}$ In 2005 , the estimate was that $45.2 \%$ of all forcible rapes and $30.2 \%$ of all sexual assaults were reported. ${ }^{191}$ In $2004,56.8 \%$ of all forcible rapes and $25.7 \%$ of all sexual assaults were reported. ${ }^{192}$

Even if underreporting is high, however, it does not necessarily diminish the accuracy of the recidivism studies cited above. By definition, recidivism studies consider only previously convicted sex offenders because they examine whether a person continues to reoffend after he has been convicted of a sex crime. For underreporting studies to discredit the accuracy of recidivism studies, they would have to be focused on whether victims report crimes committed by previously convicted offenders. It is entirely possible that a significant part of the high underreporting rate reflects victims who fail to report crimes committed by first-time sex offenders or individuals who have offended before but have never been caught.

One way of surmising whether sex crimes by convicted sex offenders are underreported relative to those committed by first-time or previously unconvicted offenders is to consider the proportion of sex-crime arrests of individuals who were not previously convicted of a sex offense as compared with those who were. The 2003 Department of Justice study found that 513 released sex offenders were arrested for a new sex crime

189. See Erin Khorram, Crossing the Limit Line: Sexual Abuse and Whether Retroactive Application of Civil Statutes of Limitation are Legal, 16 U.C. DAVIS J. JUV. L. \& POL. 391, 407-08 ("First, the child has to recognize what is happening is wrong. Second, the victim needs to be willing to come forward and tell someone about the abuse before any action can proceed, and unfortunately, many children are ashamed and embarrassed about the sexual abuse and, thus, are hindered from coming forward. Third, the child needs to be honestly believed by someone who can do something.").

190. U.S. DeP'T OF JUSTICE, CRIMINAL Victimization, 2006 (2007). Although changes were made to the NCVS in 2006 that prevent comparison of national level estimates from previous years, it is still worth reporting prior findings. Id. at 1 .

191. U.S. Dep't of Justice, Criminal Victimization in the United States, 2005 Statistical Tables tbl.91 (2006).

192. U.S. Dep'T OF JUSTICE, CRIMINAL Victimization IN THE UNITED States, 2004 STATISTICAL TABLES tbl.91 (2006). The National Crime Victimization Survey (NCVS) estimates crime victimization across the United States using a nationally representative sample of households. In 2006, 76,000 households and 135,300 individuals ages 12 years and above were interviewed by the U.S. Bureau of the Census. The Bureau of Justice Statistics (BJS) then used these interviews to estimate the extent of crime victimization. Reporting rates were similar for the three-year period studied in the 2003 Department of Justice report. In $1994,36.1 \%$ of forcible rapes and $40.7 \%$ of sexual assaults were reported to the police. Id., 1994 STATISTICAL TABLES tbl.91 (1997). In 1995, 35.3\% of forcible rapes and $27.9 \%$ of sexual assaults were reported to the police. Id., 1995 STATISTICAL TABLES tbl.91 (2000). In $1996,40.6 \%$ of forcible rapes and $24.5 \%$ of sexual assaults were reported to the police. Id., 1997 STATISTICAL TABLES tbl.91 (2000). In $1997,46.4 \%$ of all forcible rapes were reported to the police, and $9.3 \%$ of all attempted rapes were reported to the police. Id. The strikingly low percentage of those reporting sexual assaults may be explained by the fact that the estimate was made based on approximately ten or fewer sample cases. 
as compared with 3,328 released non-sex offenders arrested for a new sex crime. ${ }^{193}$ Among released individuals arrested for sex crimes, $86.5 \%$ had not been convicted of a prior sex offense. ${ }^{194}$ These data suggest that more sex crimes are actually being committed by those who have not been previously arrested for a sex crime than by those who have experienced a previous arrest. Unless there is some reason to think that victims are less likely to report a crime against a repeat offender, it makes sense to think that underreporting is disproportionately benefitting those who have never offended before or at least never before been caught.

Indeed, it would make sense that underreporting would be less likely when the alleged perpetrator is a known sex offender. It seems less likely that a victim would fail to report if the alleged perpetrator is already branded as a sex-crime perpetrator. Not all former convicted sex offenders will have their histories known, but with mandatory registration of convicted sex offenders and the availability of criminal records on the internet, such personal history is more likely to be known that in previous generations. The Jacob Wetterling Act requires that sex offenders register their addresses with the local police station, and Megan's Law requires that this information be made available to the public. ${ }^{195}$ Furthermore, when sex offenders are released from custody, they often receive strict parole or probation supervision. If one of these individuals committed a sex crime, it seems more likely that a victim's report would be taken seriously, which in turn would make the victim more likely to report. Furthermore, victims may be more willing to report a crime from a known perpetrator because they think he deserves to be punished and prevented from continuing to violate others.

\section{RECOGNIZING THE LIMITS OF OUR KNOWLEDGE AND ABILITY TO PREDict Who WiLL OfFEND IN THE FutURE}

In deciding whether to admit propensity evidence, judges must

193. A few advocates of Rules $413-414$ have used this fact to argue that the recidivism rate for sex crimes is particularly high. See, e.g., Commonwealth v. Maldonado, 838 A.2d 710, 716 n.8 (Pa. 2003) (quoting McKune v. Lile, 536 U.S. 24, 34 (2002)) ("When convicted sex offenders reenter society, they are much more likely than any other type of offender to be rearrested for a new rape or sexual assault."); Kahn, supra note 33, at 652-53 ("Another distinguishing factor of sex crimes is the high recidivism rates among sex offenders. According to a 2003 Department of Justice report, sex offenders were rearrested for new sex crimes within three years of release at a rate four times greater than other released convicts. Department of Justice data concluded that '[r]eleased rapists were 10.5 times as likely as non-rapists to be arrested for rape' and that people convicted of sexual assault were '7.5 times as likely as those convicted of other crimes to be arrested for a new sexual assault.'”).

194. DOJ, supra note 105 , at 1 .

195. See U.S Dep't of Justice, Solutions for Safer Communities (2011), available at http://www.ojp.usdoj.gov/BJA/what/02ajwactcontents.html. 
determine whether such evidence is substantially more unfairly prejudicial than it is probative. Such an evaluation begs an important question: can judges accurately assess the probative value of uncharged conduct? Practically, we suspect the answer is no.

In 1978, a task force of the American Psychological Association reported:

It does appear from reading the research that the validity of psychological predictions of dangerous behavior, at least in the sentencing and release situation ... is extremely poor, so poor that one could oppose their use on the strictly empirical grounds that psychologists are not professionally competent to make such judgments. ${ }^{196}$

In a clinical assessment, forensic psychologists and psychiatrists conduct interviews, review case files, perform psychological testing, and then use that information as the basis for a clinical opinion on whether a person is likely to reoffend. ${ }^{197}$ Although there is some disagreement regarding whether clinicians can accurately predict future dangerousness, ${ }^{198}$ most experts believe that they cannot. ${ }^{199}$ Studies have shown that clinical predictions are not much more accurate than chance. ${ }^{200}$

One potential problem is that factors that would seem to be intuitively linked to risk are not. For example, denial of the charges and low treatment motivation are not linked to recidivism. ${ }^{201}$ Nor are general psychological problems, ${ }^{202}$ alcohol abuse, or the accused's being abused as a child predictors for reoffending. ${ }^{203}$ Factors related to the crime, like low empathy for the victim and degree of sexual contact, are also unassociated with recidivism. ${ }^{204}$

196. American Psychological Association, Report of the Task Force on the Role of Psychology in the Criminal Justice System. AMERICAN PsychOLOGIST 1099, 1110 (1978).

197. R. Karl Hanson, What Do We Know About Sex Offender Risk Assessment?, 4 PSYCH. PUB. POL. \& L. 50, 54 (1998).

198. See Thomas R. Litwack, Actuarial Versus Clinical Assessments of Dangerousness, 7 PsYCH., PUB. POL. \& L. 409 (2001).

199. Hanson, supra note 197; John Monahan, The Clinical Prediction of Violent BEHAVIOR (1982); Vernon L. Quinsey \& Rudolf Ambtman, Variables Affecting Psychiatrists' and Teachers' Assessments of the Dangerousness of Mentally III Offenders, 47 J. CoNsulting \& CLINICAL PsYCH. 353 (1979); Vernon L. Quinsey \& Anne Maguire, Maximum Security Psychiatric Patients: Actuarial and Clinical Prediction of Dangerousness, I J. INTERPERSONAL VIOLENCE 143 (1986).

200. Hanson \& Bussière, supra note 126, at 356. $r=10$ for sexual recidivism. In a meta-analysis of ten studies (total sample size $=1,453$ ) that evaluated the predictive accuracy of clinical assessment in predicting sexual recidivism, the average correlation between clinical prediction of sex-offender recidivism and actual recidivism was just .10. Hanson, supra note 197, at 54.

201. Hanson \& Bussière, supra note 126, at 348-62.

202. Sexual Offender Recidivism Risk, supra note 142 , at 158.

203. Hanson, supra note 197, at 56; Hanson \& Bussière, supra note 126, at 353.

204. Sexual Offender Recidivism Risk, supra note 142, at 158. 
If trained psychologists who have actually spoken at length with their patients cannot predict recidivism, it is difficult to understand how a judge would be able to do so after reading a police or probation report. ${ }^{205}$ It is even harder to understand why a legal rule would allow such evidence before the jury, given the many ways that jurors will overvalue and distort it (not to mention the vast prejudice such evidence engenders, which is not the subject of this Article).

Nevertheless, the rules of evidence clearly delegate the job of assessing the probative value of prior bad acts to the trial judge. The legislative history indicates that in applying the Rule 403 balance to Rules $413-414$, in the vast majority of cases, the judge should find evidence of prior sexual misconduct presumptively probative. ${ }^{206}$ In essence, Congress has declared how the Rule 403 balance must normally come out. ${ }^{207}$ Whether this is a desirable or even constitutional allocation of power between Congress and the courts is highly questionable. ${ }^{208}$ In our opinion, courts have been overly deferential to the legislative assessment that prior bad acts are particularly probative in sex crimes. The determination of the balance between probative value

205. G. Adam Cossey, A Dangerous Leap: The Admission of Prior Offenses in Sexual-Assault and Child-Molestation Cases in Arkansas, 61 ARK. L. REV. 107, 122 ("Psychological science has, in fact, had a very difficult time predicting the risk of sexual offenders reoffending. If scientists have had this much trouble, just how did the Arkansas courts make this determination?").

206. See United States v. Enjady, 134 F.3d 1427, 1431, 1433 (10th Cir. 1998) ("Rule 403 should be used infrequently, reflecting Congress' legislative judgment that the evidence 'normally' should be admitted."); United States v. Mound, 149 F.3d 799, 802 (8th Cir. 1998) (applying underlying legislative judgment that probative value of Rule 413 evidence "is normally not outweighed by any risk of prejudice or other adverse effects"); 140 CONG. REC. 23603 (daily ed. Aug. 21, 1994) (remarks of principal House sponsor, Rep. Molinari) ("To implement the legislative intent, the courts must liberally construe these rules to provide the basis for a fully informed decision of sexual assault and child molestation cases, including assessment of the defendant's propensities and questions of probability in light of the defendant's past conduct.").

207. There is a presumption in favor of admissibility under these rules based on "the strong legislative judgment that evidence of prior sexual offenses should ordinarily be admissible." United States v. Gabe, 237 F.3d 954, 959 (8th Cir. 2001) (quoting United States v. LeCompte, 131 F.3d 767, 769 (8th Cir. 1997)); State v. Monahan, 2012 WL 2499662 (Ariz. Ct. App. 2012) (discussing the "probative value of Defendant's aberrant sexual propensity to commit the charged crimes"); see also United States v. Donaldson, 2012 WL 2317343, at *3 (W.D.N.Y. 2012) ("While this Court recognizes the inherent potential prejudice of this type of evidence, it is important to note that the Second Circuit has repeatedly recognized that in sexual assault and child molestation cases, the presumption is that evidence of prior acts of sexual assault or child molestation is relevant and probative, and that its probative value is normally not outweighed by any risk of prejudice.").

208. For a critique of this approach, see Eileen Scallen, Analyzing "The Politics of [Evidence] Rulemaking", 53 HASTINGS L.J. 843, 856, 877-80 (2002) (criticizing the Third Circuit in Johnson v. Elk Lake School District, 283 F.3d 138, 154-55 (3d Cir. 2002), for using David Karp's speech, memorialized later in a law review article, as legislative history in interpreting Rule 415, the civil analog to Rules 414-415); Aviva Orenstein, Deviance, Due Process, and the False Promise of Federal Rule of Evidence 403, 90 CORNELL L. REV. 1487, 1557-59 (2005); Rosanna Cavallaro, Federal Rules of Evidence 413-415 and the Struggle for Rulemaking Preeminence, 98 J. CRIM. L. \& CRIMINOLOGY 31 (2007). 
and prejudice is, by its very nature, a contextualized determination made on a case-by-case basis. If indeed all prior sex misconduct were admissible, the Rule 403 balance would not be necessary; everything would come in. In fact, however, all courts that have considered the question have determined that the Rule 403 balance is essential to due process. Without a Rule 403 balance, Rules $413-414$ would be rendered unconstitutional. ${ }^{209}$ Therefore, the balance must have some content and meaning.

Some jurisdictions have developed lists of factors to consider in performing the Rule 403 balance. ${ }^{210}$ Generally, when courts find the probative value of prior sexual misconduct low, it is because they focus on the dissimilarities between the prior bad acts and the charged conduct. ${ }^{211}$ Although questions of similarity are important in this regard, courts must further refine and reinvigorate the weighing of probative value. A sophisticated understanding of the factors that actually affect recidivism rates cannot undo the poor policy and scientific know-nothingness of the current rules. Nevertheless, it can assist courts in wisely applying them to do the least injustice.

\section{What SHOUld Judges CONSIDER IN DETERMINING THE ADMISSIBILITY OF PROPENSITY EVIDENCE?}

This Article has challenged the assumption that propensity evidence in sex cases is particularly probative. Despite the concerns raised here about the false premises based on mistaken notions of recidivism, and raised elsewhere about due process and basic fairness, we realize that Rules 413-414 and their state analogs are popular and unlikely to be revised any time soon. ${ }^{212}$ In light of that, we offer some specific advice to district court judges on how, while respecting the legislative mandate, they can nevertheless apply Rule 403 in light of the psychological and criminological evidence we have presented. Our observations and advice should also be particularly helpful in the state jurisdictions that employ common-law rules allowing evidence of the accused's propensity in sex crimes.

As we have demonstrated, the recidivism rate for sex offenders is

209. See United States v. Enjady, 525 U.S. 887 (1998); Orenstein, supra note 208.

210. See, e.g., United States v. Seymour, 468 F.3d 378 (6th Cir. 2006).

211. United States v. Meacham, 115 F3d 1488, 1492 (10th Cir. 1997) (admitting a thirty year-oldprior act of sexual misconduct, where prosecutor argued that "'[p]eople that have an aberrant sexual behavior, such as the defendant does, you don't get over that .... [W] ith things like sexual orientation towards children, a sexual interest in children, that doesn't change unless you get some intervention"').

212. See Orenstein, supra note 208 (noting that these rules are here to stay and dividing suggestions for improvement into those that Congress should do, but will not, and those that courts can do). 
actually lower than for many other crimes in which the propensity rule does not apply. Karl Hanson, probably the most widely cited scholar on sex-offender recidivism, wrote, "If few offenders recidivate, as is often the case in sexual offender outcome studies, then the simplest way to maximize the percentage correctly classified is to predict that no one will reoffend." 213 Thus, despite the license offered by Rules 413-414 and their state analogs, judges should evaluate the probative value of past sex crimes in current cases with nuance and care. Instead of just assuming that a person offended before and so he did it again, judges should start their inquiry with the understanding that most offenders do not in fact recidivate. Information in this article could assist the court in recalibrating the presumed high probative value of prior sex crimes. In light of this more sophisticated notion of probative value and a casespecific assessment of unfair prejudice, judges should feel empowered to reject some evidence admitted under these rules.

\section{A. Length of Time Since Prior Misconduct}

Perhaps the most important contribution we can make to judges' assessments of probative value is to educate the judiciary on the effect of lapse of time on recidivism. Logically, one can assume that the longer the span between past conduct and current charges, the less valuable the prior bad act is in assessing current conduct. (Ironically, however, at least one court actually used the length of time to argue that the prior act was more probative because the deviance was so longstanding). ${ }^{214}$ Some federal courts do use length of time as a factor that diminishes probative value. ${ }^{215}$ Some state courts that have adopted Rule 413-414 analogs have inserted a time requirement. ${ }^{216}$ However, many courts do not sufficiently value the passage of time as a factor. Some courts note that "[t]he legislative history of Rule 414 reveals that Congress meant its temporal scope to be broad, allowing the court to admit evidence of Rule 414 acts that occurred more than 20 years before trial." As the courts repeatedly explain, "Remoteness in time,

213. Hanson, supra note 197, at 53.

214. See People v. Frazier, 107 Cal. Rptr. 2d 100, 108 (Ct. App. 2001).

215. Seymour, 468 F.3d at 385-86; see also United States v, Kelly, 510 F.3d 433, 437 (4th Cir. 2007) (listing as one factor "the temporal proximity between the two crimes"); United States v. Guardia, 135 F.3d 1326, 1331 (10th Cir. 1998) (including "closeness in time of the prior acts to the charged acts" as a factor in the Rule 403 balance).

216. Cf. State v. Gresham, 269 P.3d 207 (Wash. 2012) (listing " $[t]$ he closeness in time of the prior acts to the acts charged" as a factor in conducting the Rule 403 balance).

217. United States v. Larson, 112 F.3d 600, 605 (2d Cir, 1997); see also 140 CONG. REC. 23603 (daily ed. Aug. 21, 1994) (statement of Rep. Molinari) (quoted in part in Gabe, 237 F.3d at 960 n.4) ("[A]s a practical matter, evidence of other sex offenses by the defendant is often probative and properly 
especially when the prior crime was substantially similar, does not render the conviction inadmissible." 218 Prior acts from twenty or even thirty years before the current charges are admitted under Rules 413$414^{219}$

A time limitation is already in the rules of character evidence regarding criminal convictions of witnesses (which includes the accused). Under Federal Rule of Evidence 609(b), a prior crime is not admissible to impeach a witness if more than ten years have elapsed since the date of conviction ${ }^{220}$ or confinement ${ }^{221}$ (whichever is longer) unless the probative value substantially outweighs the prejudicial effect. ${ }^{222}$ Consequently, except in exceptional circumstances, crimes over ten years old are not admitted to impeach a witness' character. Unfortunately, such a sensible limitation was not built into Rules 413414-even though one of their sponsors, Senator Robert Dole, did express his opinion that any prior act over ten years old would not be generally admissible under the Rules. ${ }^{223}$

In light of the facts that the risk of recidivating drops over time, and that the longer a person remains in the community without offending, the less likely he is to reoffend, judges should be highly skeptical of the probative value of sex crimes from long ago. Accordingly, a ten-year time lag should be deemed to undermine significantly the probative value of prior sexual misconduct. Even though Rules 413-414 do not

admitted, notwithstanding very substantial lapses of time in relation to the charged offense or offenses."); United States v. Gabe, 237 F.3d 954, 960 (8th Cir. 2001) ("When Rule 414 was enacted, Congress expressly rejected imposing any time limit on prior sex offense evidence.").

218. United States v. Levinson, 2011 WL 1102841, at *4 (S.D. Fla. 2011). This is particularly true where the accused has been incarcerated and has had little opportunity to recidivate. United States v. Merz, 396 Fed.App'x 838, 843 (3d Cir. 2010) (noting that for many of the thirteen years between offenses the accused was in prison).

219. For examples of judges admitting propensity evidence that is over ten years old, see United States v. Carino, 368 Fed. App'x 929 (11th Cir. 2010) (evidence of molestation 32 years before trial properly admitted); United States v. Benally, 500 F.3d 1085 (10th Cir. 2007) (affirming admission of rape of sister-in-law forty years before charged offense under Rule 414); United States v. Drewry, 365 F.3d 957, 960 (10th Cir. 2004) (finding "[s]ufficient factual similarity" between twenty-five-year-old uncharged child molestation and the charged offense permitted admission of evidence "that might otherwise be inadmissible due to staleness"); United States v. Gabe, 237 F.3d 954, 959-60 (8th Cir. 2001) (upholding admission of sexual molestation committed twenty years before charged offenses where prior acts were "almost identical" to charged crimes); see also Orenstein, supra note 208, at 1495 n.23.

220. United States v. Lopez, 979 F.2d 1024, 1033 (5th Cir. 1992).

221. United States v. Daniel, 957 F.2d 162, 168 (5th Cir. 1992).

222. FED. R. EVID 609(b). There is a clear presumption against admitting remote character evidence. See United States v. Estes, 994 F.2d 147 (5th Cir. 1993); see also United States v. Avants, 367 F.3d 433, 448-49 (5th Cir. 2005); United States v. Privett, 68 F.3d 101 (5th Cir. 1995).

223. In discussing the value of prior sexual misconduct Senator Dole stated that "[i]f it had not happened for 10 years, it probably would not have any value." 139 CONG. REC. 27549 (daily ed. Nov. $4,1993)$. 
themselves contain a time limit such as the one included in Rule 609, judges employing their discretion should generally consider prior sex crimes older than ten years as lacking sufficient probative value.

\section{B. Type of Crime}

The risk of recidivating differs depending on the specific sex crime. Judges should be especially reluctant to admit propensity evidence against accused incest offenders because their risk of recidivating is low, ${ }^{224}$ and the unfair prejudice may be especially high given juror revulsion at incest, particularly when the victim is a child. Such cases may be emotionally difficult for judges as well.

\section{Age of Offender}

The significance of age in recidivating cannot be underestimated. The older the accused rapist or child molester, the more wary judges should be of admitting propensity evidence. For those accused of committing child molestation, judges should be especially cautious in admitting propensity evidence as the accused reaches the age of 50 and above. Judges should be aware that rapists are younger than other types of sex offenders, and as they age, their risk of recidivating steadily declines. On the other hand, we acknowledge that if recidivism rates are deemed a fair proxy for probative value, ${ }^{225}$ judges should consider the increased risk of recidivating for incest offenders between the ages of 18 and 24 as enhancing the probative value of such prior bad acts.

\section{Gender of the Offender}

Women have a very low recidivism rate, and experts do not know which factors are predictive of reoffending. In light of that, one could counsel that judges should exercise extreme caution in admitting propensity evidence against women. We recognize, however, that relying on gender exclusively to diminish probative value would raise the risk of discrimination and equal protection violations.

224. In one study, Hanson found that incest offenders had a recidivism rate of $8.4 \%$ as compared with $17.1 \%$ for rapists and $19.5 \%$ for extra-familial child molesters. Hanson, supra note 146, at 1053 .

225. For many reasons we resist the idea that it is, but we are trying to stay within the confines of the debate and the limits of what trial judges can practically accomplish with their discretion under Rule 403. 


\section{CONCLUSION}

The propensity rules are premised on the belief that sex offenders are a discrete group of deviants who will continue to reoffend no matter what. This view, however, is not supported by most existing psychological and criminological research. The recidivism rate for sex offenders is remarkably low, much lower than for crimes in which the propensity ban remains in force. In addition, the longer a released offender refrains from reoffending, the less likely he is to reoffend. In part this is because as offenders age, they are less likely to reoffend.

Furthermore, studies show that not all sex offenders are the same. Incest offenders (those who victimize their biological children as well as those who violate their stepchildren) have much lower recidivism rates than extra-familial child molesters. Yet, the evidence rules make no such distinction among types of perpetrators who sexually abuse children. Furthermore, not everyone who molests children is a pedophile. Some men who commit sex crimes are attracted to children but others choose a child for sexual gratification because the child is an available easy target.

Abundant empirical evidence also contradicts the deviant, recidivist image when applied to adult rape. In a 2004 DOJ study, 5\% of rapists were rearrested for a sex crime within three years of release from prison, and just $2.5 \%$ were rearrested for rape. ${ }^{226}$ In addition, rapists were younger than both extra-familial child molesters and incest offenders, and their risk of recidivating dropped steadily as they aged. ${ }^{227}$

Sex offenders are not more likely than any other type of offender to reoffend for the same crime. Although it is true that sex offenders are more likely than non-sex offenders to be rearrested for a sex crime, they are less likely than other offenders to recommit the crime for which they were arrested. Indeed, the only group of offenders less deserving of the propensity rationale is convicted killers. ${ }^{228}$

We do not contend that the propensity rationale never makes sense for sex offenders and do not dispute that some offenders do reoffend compulsively. The problem, however, is whether a judge would be able to tell who those offenders are. As we show, clinicians are notoriously inaccurate at predicting who will reoffend, and there is no reason to think that judges will be any better.

Once a jury is faced with a bona fide rapist or child molester-that is, someone who has been accused or convicted before-the temptation to

226. DOJ, supra note 105 , at $28,34$.

227. Hanson, supra note 146 , at 1056.

228. Just $1.2 \%$ were rearrested for homicide within three years after release from prison. LANGAN \& LEVIN, supra note 116, at 9. 
demonize that person and ignore the individual facts of the case are enormous. This should provide all the more incentive for judges to carefully and thoughtfully access the probative value of past sex crimes in each individual case. 